\title{
Food combinations for cholesterol lowering
}

\author{
Janice I. Harland* \\ HarlandHall Associates, The Stables, Ranbury Ring, London Road, Poulton, Cirencester, Gloucestershire GL7 5HN, UK
}

(Submitted 25 January 2012 - Final revision received 28 May 2012 - Accepted 18 June 2012 - First published online 15 October 2012)

\section{Abstract}

Reducing elevated LDL-cholesterol is a key public health challenge. There is substantial evidence from randomised controlled trials (RCT) that a number of foods and food components can significantly reduce LDL-cholesterol. Data from RCT have been reviewed to determine whether effects are additive when two or more of these components are consumed together. Typically components, such as plant stanols and sterols, soya protein, $\beta$-glucans and tree nuts, when consumed individually at their target rate, reduce LDL-cholesterol by 3-9\%. Improved dietary fat quality, achieved by replacing SFA with unsaturated fat, reduces LDL-cholesterol and can increase HDL-cholesterol, further improving blood lipid profile. It appears that the effect of combining these interventions is largely additive; however, compliance with multiple changes may reduce over time. Food combinations used in ten 'portfolio diet' studies have been reviewed. In clinical efficacy studies of about 1 month where all foods were provided, LDL-cholesterol is reduced by $22-30 \%$, whereas in community-based studies of $>6$ months' duration, where dietary advice is the basis of the intervention, reduction in LDL-cholesterol is about $15 \%$. Inclusion of MUFA into 'portfolio diets' increases HDL-cholesterol, in addition to LDL-cholesterol effects. Compliance with some of these dietary changes can be achieved more easily compared with others. By careful food component selection, appropriate to the individual, the effect of including only two components in the diet with good compliance could be a sustainable $10 \%$ reduction in LDL-cholesterol; this is sufficient to make a substantial impact on cholesterol management and reduce the need for pharmaceutical intervention.

Key words: Food component selection: Cholesterol lowering: Stanols: Sterols: Soya protein: $\beta$-Glucans: Tree nuts

\section{Introduction}

CHD is a leading cause of premature mortality and disability-adjusted life years in Western society with 2 million deaths in the European Union and 4.3 million deaths in Europe $^{(1)}$. Within the European Union, the economic cost of CVD is substantial and has been calculated to be $€ 192$ billion annually in direct and indirect healthcare costs ${ }^{(1)}$.

While the causes of CHD are multifactorial, many of these factors are related to lifestyle such as tobacco smoking, lack of physical activity, and dietary habits and, as such, are modifiable. Other modifiable risk factors include elevated blood pressure, type 2 diabetes and dyslipidaemias ${ }^{(2)}$. The importance of raised blood cholesterol as a modifiable risk factor for CHD is well established ${ }^{(3)}$. The WHO estimates that over $60 \%$ of CHD and $40 \%$ of ischaemic stoke in developed countries is due to total blood cholesterol levels in excess of the theoretical minimum $3.8 \mathrm{mmol} / \mathrm{l}^{(3)}$. For some time, public health campaigns such as the National Cholesterol Education Program and Joint British Societies' guidelines have emphasised reducing elevated LDL-cholesterol to lower CHD risk $^{(4,5)}$. Furthermore, it has been suggested that every $1.0 \mathrm{mmol} / \mathrm{l}$
$(39 \mathrm{mg} / \mathrm{dl})$ reduction in LDL-cholesterol is associated with a $22 \%$ reduction in the risk of CVD mortality and morbidity. Consequently, the reduction of elevated LDL-cholesterol is a significant public health goal.

A central recommendation in guidance given to many Western populations is the need to reduce fat intake, particularly saturated fat and trans-fat ${ }^{(6)}$. The conventional approach to SFA reduction has been to exclude food high in saturates or identify low-fat alternatives such as low-fat dairy products, meat products, etc. While this approach can be effective, recent advice suggests that, ideally, SFA reduction should also be associated with improvements in fat quality achieved by substituting SFA with unsaturated fat ${ }^{(7,8)}$, with some suggesting that the preferred source of these fats is MUFA ${ }^{(8)}$. Furthermore, in a recently produced unified theory based on evolutionary, historical, global and modern perspectives relating dietary fat quality and CHD prevention, it was identified that reduction or elimination of trans-fatty acids and replacement of SFA with MUFA may provide cardiovascular benefits ${ }^{(9)}$. Moreover, replacement of medium-chain $n-6$ PUFA (for example, linoleic acid), moderate consumption

Abbreviations: ALA, $\alpha$-linolenic acid; EFSA, European Food Safety Authority; RCT, randomised controlled trial.

*Corresponding author: Dr Janice I. Harland, fax +44 1285 851176, email jan.harland@harlandhall.co.uk 
of medium-chain $n$-3 PUFA (for example, $\alpha$-linolenic acid; ALA) and increased consumption of long-chain $n$-3 PUFA (for example, EPA and DHA) may provide beneficial cardiometabolic effects and are unlikely to do any harm ${ }^{(9)}$.

Decreasing SFA intake conventionally was the first therapeutic option recommended to individuals to lower blood cholesterol, however, of increasing importance is the use of effective combinations of cholesterol-lowering dietary components, such as $\beta$-glucans, soya protein and plant stanols and sterols as an approach to managing blood cholesterol (National Cholesterol Education Program Panel III guidelines $)^{(4)}$. A dual approach, based on modification of both improved fat quality and use of cholesterol-lowering food components, maximises the beneficial effect on blood lipids, thereby reducing the risk of heart disease and also other metabolic conditions ${ }^{(7)}$

A number of foods, many of them the so-called functional foods or nutriceuticals, have been identified that modify blood lipids. These foods have traditionally been considered as a single addition to a lipid-modification diet. A more sophisticated approach to combining foods with enhanced cholesterol-lowering properties is that adopted in the 'portfolio diet' ${ }^{\text {(10) }}$. This terminology, adopted by Jenkins over a decade ago, refers to a low-fat vegan or vegetarian diet enhanced by the inclusion of plant stanols or sterols, soya protein, viscous fibre and tree nuts ${ }^{(11)}$. Latterly the 'portfolio diet' has been developed by the addition of MUFA ${ }^{(12)}$

It is suggested that as important as either looking at these components in isolation, or as sophisticated combinations, is the role that simple combinations of cholesterol-lowering foods can play in meeting the dual objective of improving the fat quality of the diet and blood cholesterol lowering. In order to establish baseline values for the key food and food components that can modify blood cholesterol and to understand the degree to which they are additive, a search of the literature was conducted to identify the most up-to-date information relating to their individual and combined potential. Information relating to each food or component was extracted and converted into a common format for subsequent tabulation of the data.

\section{Methods}

A search of the scientific literature (Medline, December 2011) was used to identify papers, specifically randomised controlled trials (RCT) and meta-analyses, conducted where the effect of a food/food component intervention on blood lipids was assessed. Search terms were 'cholesterol' or 'blood lipids' and 'the food name' and 'meta'. The designated 'food names' included beta-glucan(s), soy(a) protein, nuts, plant stanol and sterol. In addition, the search terms 'cholesterol' or 'blood lipids' and 'portfolio' were used to identify studies conducted using a portfolio approach. These searches were complemented by a hand search of key reviews and meta-analyses. The key findings from identified papers were extracted and the information converted into a common form. For example, all data were converted to $\mathrm{mmol} / \mathrm{l}$ from $\mathrm{mg} / \mathrm{dl}$ by use of the factor 0.02586 for total cholesterol, LDL- and HDL-cholesterol and by use of the factor 0.01 125 for TAG. In order to assess the relative effects on fat quality following dietary modification (in g) and LDL-cholesterol reduction (as a percentage reduction compared with control treatment) as detailed in Tables 2 and 5, baseline LDL-cholesterol concentration has been assumed to be $3.75 \mathrm{mmol} / \mathrm{l}$, if no specific value is given.

\section{Results and discussion}

The focus of the present review is on the reduction of total and LDL-cholesterol, as this appears to be where dietary manipulations are most effective. However, this approach is not intended to undermine the valuable contribution that can be made by the maintenance of or an increase in HDL-cholesterol. It has been argued, particularly for those at risk for CHD, that the total cholesterol:HDLcholesterol ratio is a better assessment of risk than single lipid components ${ }^{(5)}$. Also important to coronary risk is elevated TAG, particularly in diabetics and other subsectors of the population, where a combination of measures may be appropriate ${ }^{(13-15)}$. Reference to the effect of food and food components on all main lipid components will be made where possible.

\section{Macronutrient changes that reduce blood lipids}

There are many ways to predict the effect of macronutrient intake on blood lipid changes and CHD risk; see, for example, Givens ${ }^{(16)}$, who used five models based on prediction equations from the original proposed by Keys ${ }^{(17)}$. Traditionally, SFA reduction has been the key tactic employed to reduce blood cholesterol levels to lower the risk of both CVD and diabetes. Generally, LDL-cholesterol increases proportionally to the amount of SFA in the diet. However, advice has been less conclusive with regards to the best replacement for SFA in the diet, particularly as a desirable increase in HDL-cholesterol was reported in a meta-analysis of sixty studies that evaluated the effect of replacing carbohydrate with SFA ${ }^{(18)}$. However, the replacement of large amounts of dietary SFA with carbohydrate should be avoided, as fasting TAG concentrations may increase and dyslipidaemia associated with the insulin resistance syndrome may be induced, which would be counterproductive, particularly in diabetics ${ }^{(19)}$.

A role has been identified for the enhanced intake of either cis-MUFA or PUFA as the most effective replacements of dietary SFA to reduce CHD risk ${ }^{(18)}$. However, the authors also reported that the effect on LDL-cholesterol may be markedly different to the effect on the total:HDLcholesterol ratio, which they indicated was a better indicator of CVD risk, a view shared by the Joint British 
Societies in their recommendations for CVD assessment ${ }^{(5)}$. It was calculated that the replacement of $1 \%$ carbohydrate energy with cis-MUFA or PUFA improved total:HDLcholesterol ratio by about $0.03 \mathrm{mmol} / 1(P<0.001)$, whereas LDL-cholesterol was reduced by about $0.1 \mathrm{mmol} / 1$ $(P<0.01)$ when replaced by MUFA and about $0.2 \mathrm{mmol} / 1$ $(P<0 \cdot 001)$ when replaced by PUFA. The same replacement with SFA increased LDL-cholesterol by about $0.03 \mathrm{mmol} / 1$ $(P<0.001)$.

Oils with the highest MUFA content most frequently consumed in Western society are olive and rapeseed. The predicted change in total cholesterol:HDL-cholesterol ratio when 'mixed fat' that constituted $10 \%$ of energy of the average US diet was replaced isoenergetically with either olive or rapeseed oil has been calculated and the improvement was about $0 \cdot 1$ and $0.12 \mathrm{mmol} / 1$, respectively $^{(18)}$. By reference to a meta-analysis of nine studies, where rapeseed oil was either added to, or substituted for SFA in the diet, it was calculated that each $1 \mathrm{~g}$ of SFA intake reduction was associated with reductions in both LDL- and total cholesterol of $0.03 \mathrm{mmol} / 1$, while each $1 \mathrm{~g}$ increase in either MUFA or PUFA reduced total cholesterol by 0.05 and $0.09 \mathrm{mmol} / 1$, respectively, and LDL-cholesterol by 0.04 and $0.08 \mathrm{mmol} / 1$, respectively ${ }^{(20)}$. It was also calculated that each $10 \mathrm{~g}$ increase in MUFA or rapeseed oil intake was associated with a reduction in total and LDL-cholesterol of 9.8 and $5.8 \%$, respectively.

There are also a number of epidemiological studies that demonstrate a reduction in CHD risk with moderate- to high-fat diets rich in MUFA; see, for example, the Seven Countries Study ${ }^{(21)}$, the Nurses' Health Study ${ }^{(22)}$ and the large-scale intervention studies OmniHeart and KANWU $^{(23,24)}$.

A further consideration is that while PUFA, especially long-chain $n$-3 PUFA, reduce CHD risk, there is concern that consumption of $n$ - 6 PUFA, particularly linoleic acid, is at an all-time high in Western society ${ }^{(9)}$. Furthermore, it has been suggested that the amount of $n$ - 6 PUFA should not increase further ${ }^{(25)}$, and the ratio of $n-6: n-3$ PUFA should reduce ${ }^{(26)}$.

\section{Foods or components that reduce blood lipids}

The 'portfolio diet' is based on increasing intake of plant stanols and sterols, soluble (viscous) fibre, soya protein and tree nuts to enhance the cholesterol-reducing effect of a plant-based diet. These dietary components are those for which most evidence exists and for which health claim(s) have been permitted in one or more countries. In addition, there are a number of foods where blood lipid modification evidence is accumulating and that may have potential as cholesterol-lowering agents; these include dark chocolate, green tea, flaxseed and garlic. As evidence relating to these various foodstuffs is limited, their role has not been assessed in detail. However, as further clinical research becomes available, they, too, can be incorporated into a cholesterol-lowering regimen. Neither does this list of foods claim to be exhaustive, but provides an insight into the evidence that currently exists for the main cholesterol-lowering food components. Finally, there are numerous foods for which a single human study or only animal data are available; while these foods may offer potential for the future, further evidence is needed to properly assess the contribution that can be made by these foods.

\section{Plant stanols and sterols}

There is an extensive literature that has evaluated the effects of plant stanols and sterols on blood lipids.

Plant sterols and stanols are naturally occurring compounds structurally similar to cholesterol with a cellular function similar to human cholesterol. Plant sterols have a higher degree of absorption than plant stanols. There are in excess of 200 clinical studies that have evaluated the effects of these components on blood lipids, primarily in adults with normal or elevated plasma cholesterol at baseline. In 2009, the European Food Safety Authority (EFSA) assessed the scientific evidence available up to this date and a health claim was granted in Europe. The following statement was devised to be reflective of the evidence: 'Plant stanols/sterols have been shown to lower/reduce blood cholesterol'. On the basis of evidence supplied, it was estimated that $1.5-1.9 \mathrm{~g}$ plant sterols per $\mathrm{d}$ and $2 \cdot 0-2 \cdot 4 \mathrm{~g}$ plant stanols per d reduce LDL-cholesterol by an average of 8.5 and $8.9 \%$, respectively ${ }^{(27)}$. Typically for an intake of $1.5-2.4 \mathrm{~g}$ plant sterols or stanols per $\mathrm{d}$, a reduction in LDL-cholesterol of between 7 and $10.5 \%$ can be expected. A similar health claim also exists in the $\mathrm{USA}^{(28)}$. Evidence from two early analyses ${ }^{(29,30)}$ and two more recent meta-analyses ${ }^{(31,32)}$ were cited in support of the claim. In brief, the more recent analyses involved pooling of data from a large number of RCT, either eighty-four trials including 141 trial arms (6805 subjects) ${ }^{(31)}$, or fiftynine RCT $(n>4500 \text { subjects })^{(32)}$. A non-linear equation comprising two parameters (the maximal LDL-cholesterol lowering and an incremental dose step) was used to describe the dose-response curve, and the overall pooled absolute (mmol/l) and relative (\%) LDL-cholesterol-lowering effects of phytosterols were also assessed with a random-effects model ${ }^{(31)}$. The pooled LDL-cholesterol reduction was $0.34(95 \% \mathrm{CI}-0.36,-0.31) \mathrm{mmol} / \mathrm{l}$, or $8.8 \%$ for a mean daily dose of $2.15 \mathrm{~g}$ phytosterols. The impacts of subject baseline characteristics, food formats, type of phytosterols and study quality on the continuous dose-response curve were determined by regression or subgroup analyses. Higher baseline LDL-cholesterol concentrations resulted in greater absolute LDL-cholesterol reductions. No significant differences were found between dose-response curves established for plant sterols $v$. stanols, fat-based $v$. non-fat-based food formats and dairy $v$ non-dairy foods. A larger effect was observed with solid 
foods than with liquid foods only at high phytosterol doses $(>2 \mathrm{~g} / \mathrm{d})$. There was a strong tendency $(P=0.054)$ towards a slightly lower efficacy of single $v$. multiple daily intakes of phytosterols ${ }^{(31)}$. The results of this analysis are not dissimilar to the second meta-analysis in which the weighted mean net difference in LDL-cholesterol was -0.31 (95\% CI $-0.35,-0.27) \mathrm{mmol} / \mathrm{l}(P<0.0001) \mathrm{com}-$ pared with control ${ }^{(32)}$. Reductions in LDL-cholesterol levels were reported to be greater in individuals with high baseline LDL-cholesterol and when plant sterols were incorporated into fat spreads, mayonnaise, salad dressing, milk and yoghurt compared with other food products such as croissants and muffins, orange juice, non-fat beverages, cereal bars and chocolate. There has been significant product development in this area, with a wide range of products, particularly yoghurts, yoghurt-type or breakfast drinks and spreads now containing a substantial quantity of plant sterols and stanols, enabling the regular achievement of the target daily amount identified.

A further meta-analysis identified seventy-six studies, of which twenty were considered of sufficient quality for data pooling, and provides data on TAG, in addition to total and LDL-cholesterol ${ }^{(33)}$. The results of this analysis indicated that volunteers consuming foods enriched with $2.0 \mathrm{~g}$ plant stanols or sterols could significantly decrease LDL- and total cholesterol and TAG compared with control groups; mean differences were - 0.35 (95\% $\mathrm{CI}-0.47,-0.22) \mathrm{mmol} / \mathrm{l}(P<0.00001),-0.36$ (95\% CI $-0.46,-0.26) \mathrm{mmol} / \mathrm{l} \quad(P<0.00001)$ and $-0.1 \quad(95 \%$ $\mathrm{CI}-0 \cdot 16,-0.03) \mathrm{mmol} / \mathrm{l}(P=0 \cdot 004)$, respectively.

Recently, two further analyses have been performed that compare the effect of plant sterols $v$. plant stanols on serum lipid levels in healthy patients and patients with hypercholesterolaemia. In the most recent systematic review and meta-analysis, 113 publications and one unpublished study report containing 182 treatment arms met the pre-defined inclusion and exclusion criteria and were included in the assessment ${ }^{(34)}$. The maximal LDLcholesterol reductions for plant stanols (16.4\%) and plant stanol ester $(17 \cdot 1 \%)$ were significantly greater than the maximal LDL-cholesterol reductions for plant sterols $(8.3 \%)$ and plant sterol ester $(8.4 \%)^{(34)}$; however, intake was far in excess of usual target intake levels of 1.5 to $<2.5 \mathrm{~g} / \mathrm{d}$, at which level of intake the extent of LDLcholesterol reduction is comparable ${ }^{(27)}$. An analysis specifically designed to summarise direct comparisons between the effect on plant sterols and stanols on serum lipid levels demonstrated that in fourteen studies with 531 subjects, there is no statistically or clinically significant difference between plant sterols and plant stanols in their abilities to modify total cholesterol (weighted mean difference (WMD), $\quad-0.03 \quad$ (95\% CI $-0.11, \quad 0.05) \quad \mathrm{mmol} / \mathrm{l}$ $(P=0.47)$; LDL-cholesterol WMD, - 0.010 (95\% CI - 0.08, 0.06) $\mathrm{mmol} / \mathrm{l}$ (NS); HDL-cholesterol WMD, 0.001 (95\% CI $-0.03,0.02) \mathrm{mmol} / \mathrm{l}$ (NS); TAG WMD, 0.02 (95\% CI $-0.08,0.04) \mathrm{mmol} / \mathrm{l}(\mathrm{NS}))^{(35)}$.
Looking at the database of RCT and meta-analyses as a whole, there is consistent evidence indicating that both plant stanols and sterols reduce total and LDL-cholesterol by a clinically and statistically significant amount. However, whether there is a meaningful difference in the extent of the cholesterol reduction when plant stanols and sterols are included in the diet at the recommended dose and in individuals with similar baseline cholesterol and in the same food matrix is questionable.

\section{Soya protein}

The literature relating to soya protein is extensive, with over 100 RCT published and a plethora of meta-analyses. A total of eleven meta-analyses conducted with RCT that relate soya protein with or without soya isoflavones to a measure of blood lipids have been identified ${ }^{(36-46)}$, as well as a review and nomogram ${ }^{(47)}$. These meta-analyses have recently been reviewed and it was concluded that despite employing widely varying inclusion criteria, all meta-analyses published to date consistently report a reduction in total and LDL-cholesterol. The main area of difference appears to be the extent of the reported reduction in LDL-cholesterol, which was typically reported to be about $0.22 \mathrm{mmol} / \mathrm{l}$ and equivalent to a reduction of $4 \cdot 5-7 \cdot 0 \%$. HDL-cholesterol is typically increased by $0.01-$ $0.04 \mathrm{mmol} / 1$ and TAG reduced by $0.10 \mathrm{mmol} / 1$. The assessment of the effect of soya protein on blood lipids from studies conducted in the 21st century was achieved by pooling data from eligible RCT conducted with about $25 \mathrm{~g}$ soya protein; the standard mean difference in LDLcholesterol in this subset of twenty-seven studies was $-0 \cdot 22(95 \% \mathrm{CI}-0 \cdot 28,-0 \cdot 15) \mathrm{mmol} / \mathrm{l}$, which was highly statistically significant $(P<0.0001)$ and equivalent to a reduction compared with baseline of $5 \cdot 5 \%$.

A novel approach to pooling data was adopted in the analysis of Jenkins et $a l .{ }^{(48)}$. These authors determined the 'intrinsic' effect of soya protein (that related to the soya protein per se) on LDL-cholesterol, separately from the 'extrinsic' (displacement) potential of soya in replacing SFA and other components in the diet associated with elevated blood lipids. The intrinsic effect of soya to lower plasma cholesterol was derived from a meta-analysis of eleven RCT where macronutrient profiles of both soya protein and protein control diets were balanced. The results from this meta-analysis indicated a mean LDL-cholesterol reduction of $0.17 \mathrm{mmol} / 1$ ( $n 22 ; P<0.0001$ ) or $4.3 \%$ for soya, which could be attributable to the soya protein itself and not due to any other dietary factor. They then further explored the proposed 'extrinsic' effect of soya protein in displacing foods higher in SFA and cholesterol using the standard predictive equations for LDL-cholesterol, based on the isoenergetic substitution of a range of 13-58g soya protein-containing foods per $d$ for animal protein foods, for example, cows' milk, yoghurt and meat. The estimated displacement value of soya (intake 
range, $13-58 \mathrm{~g} / \mathrm{d}$ ) using typical American diets (50th percentile Third National Health and Nutrition Examination Survey (NHANES III) intake data) was a 3.6-6.0\% reduction in LDL-cholesterol, due to displacement of SFA and cholesterol from animal foods. Thus, the total LDLcholesterol reduction attributable to the combined intrinsic and extrinsic effects of soya protein foods therefore ranged from $7 \cdot 9$ to $10 \cdot 3 \%{ }^{(48)}$.

The extent to which soya protein can reduce total and LDL-cholesterol has been evaluated largely in subjects who are healthy or with modest hypercholesterolaemia, although some of the meta-analyses include subjects with familial heart disease, diabetes and the metabolic syndrome ${ }^{(36,40)}$. A further important finding from the metaanalyses is that no dose-response relationship has been identified in the range of $15-40 \mathrm{~g}$ soya protein intake and any of the changes in blood lipids, indicating that lower amounts of soya protein intake can be effective ${ }^{(43)}$.

Individual studies have compared the efficacy of different sources of soya protein, an aspect further investigated by sub-analyses conducted in recent meta-analyses ${ }^{(45,46)}$. In a well-controlled study conducted with $25 \mathrm{~g}$ soya protein that was presented as soya milk, prepared from either whole bean or isolated soya protein and compared with cows' milk, no difference was reported in the extent of LDL reduction between the two soya milks, and both resulted in LDL-cholesterol levels that were significantly lower than with cows' milk $(P=0.02)^{(49)}$. In the recent Anderson \& Bush meta-analysis, a sub-analysis of fortyseven studies evaluated the effects of food form of the soya protein on LDL-cholesterol lowering. It was concluded that different food forms of soya protein did not have significantly differing effects on net reductions of LDL-cholesterol when isolated soya protein was compared with soya protein presented as either soya milk or yoghurt or other food forms ${ }^{(46)}$.

At the present time, health claims exist in both Europe and the USA and are based upon an intake of $25 \mathrm{~g}$ soya protein being associated with lowered blood cholesterol $^{(50,51)}$. The claim can be made on foods containing a minimum content of soya protein, which is $5 \mathrm{~g}$ in Europe and $6.25 \mathrm{~g}$ in the USA. There are a wide range of food that supply $>5 \mathrm{~g}$ soya protein per serving; these include soya milk, soya yoghurts, tofu, edamame and meat replacer products such as burgers, meatballs, sausages and mince.

\section{Soluble fibre}

An interest in the role that soluble fibre could play in reducing blood cholesterol stems from research carried out in the $1970 \mathrm{~s}$ and $1980 \mathrm{~s}$. At this time, oats, pectin, guar gum and psyllium were considered to be the main sources of soluble fibre. A meta-analysis of sixty-seven RCT incorporating these fibres in the diet, at a range of inclusion of $2-10 \mathrm{~g}$ soluble fibre/d, indicated a reduction in total or
LDL-cholesterol of -0.045 (95\% CI - 0.054, - 0.035) $\mathrm{mmol} / \mathrm{l}$ per $\mathrm{g}$ soluble fibre and -0.057 (95\% CI - 0.070, -0.044) $\mathrm{mmol} / \mathrm{l}$ per $\mathrm{g}$ soluble fibre, respectively ${ }^{(52)}$. At this time it was concluded that there was no significant difference between the extent of the cholesterol reduction promoted by the various fibre sources. In recent times, analyses have focused on specific fibre type, indicating that there is a belief that all soluble fibres may not be equal, or that the term 'soluble' is not sufficiently specific. The soluble fibre component of importance for cholesterol reduction in oats has been identified as the $\beta$-glucans. Subanalyses of the data, by source of soluble fibre, indicated that a dose-response relationship existed between oat soluble fibre intake and the degree of cholesterol reduction. It could be calculated that $3 \mathrm{~g}$ soluble fibre from oats (three servings of oatmeal, $28 \mathrm{~g}$ each) could decrease total and LDL-cholesterol by approximately $0.13 \mathrm{mmol} / \mathrm{l}^{(52)}$. An earlier analysis of ten studies evaluating the effect of oats inclusion and blood lipid modification indicated a change in total cholesterol level of -0.13 (95\% CI -0.19 , $-0.017) \mathrm{mmol} / \mathrm{l}$ compared with control $^{(53)}$. In recent times, a further meta-analysis was conducted as part of the health claim application for oats ${ }^{(54)}$. In this metaanalysis, data were pooled from eighteen RCT; the overall effect was a reduction of $-0.34(95 \%$ CI $-0.42,-0 \cdot 25)$ $\mathrm{mmol} / \mathrm{l}(P<0.001)$ for total cholesterol and a reduction of -0.28 (95\% CI $-0.35,-0.22) \mathrm{mmol} / \mathrm{l}(P<0.001)$ for LDL-cholesterol. When mean study differences were plotted against dose, estimates for effects of the recommended intake of $3 \mathrm{~g}$ oat $\beta$-glucan per $\mathrm{d}$ were -0.23 $(95 \%$ CI $-0.35,-0.10)$ and -0.21 (95\% CI -0.31 , $-0 \cdot 11) \mathrm{mmol} / \mathrm{l}$ for total and LDL-cholesterol, respectively, with no significant effect on HDL-cholesterol ${ }^{(54)}$.

Barley $\beta$-glucan has also been shown to have cholesterol-lowering properties ${ }^{(55)}$. In a meta-analysis evaluating the lipid-reducing effects of barley, eight eligible trials ( $n$ 391) of 4-12 weeks' duration were identified. The inclusion of $2-10 \mathrm{~g}$ barley $\beta$-glucan lowered mean difference in total cholesterol by -0.35 (95\% CI -0.48 , $-0 \cdot 21) \mathrm{mmol} / \mathrm{l}$, LDL-cholesterol by -0.26 (95\% CI -0.36 , $-0 \cdot 16) \mathrm{mmol} / \mathrm{l}$ and TAG by $-0 \cdot 13$ (95\% CI $-0 \cdot 23,-0 \cdot 04)$ mmol/1, but did not significantly alter HDL-cholesterol. A further meta-analysis conducted with eleven eligible studies reached similar conclusions ${ }^{(56)}$. Unpublished results from a third recently conducted meta-analysis, which included only studies using barley $\beta$-glucan of $>50 \mathrm{kDa}$ molecular weight in the analysis, reported a reduction in total and LDL-cholesterol of 0.41 (95\% CI $-0.75,-0.44)$ and $0.33(95 \% \mathrm{CI}-0.42,-0.25) \mathrm{mmol} / \mathrm{l}$, respectively (both $P<0 \cdot 0001$ ) (JI Harland, M Ruffell and L Kolberg, unpublished results). By reference to a sub-analysis it was established that $3 \mathrm{~g}$ barley $\beta$-glucan was the minimum effective dose and, at this level of inclusion, LDL-cholesterol is reduced by $0.28 \mathrm{mmol} / \mathrm{l}$, a reduction of approximately $7 \%$ compared with baseline, and total cholesterol by $0.34 \mathrm{mmol} / \mathrm{l}$, a reduction of $5.7 \%$ 
compared with baseline. This is not dissimilar to estimates for calculated effects of $3 \mathrm{~g}$ oat $\beta$-glucan per $\mathrm{d}$. Barley and oats contain a similar amount of $\beta$-glucans $(3 \cdot 5-5.9 \% \mathrm{DM})$; it seems unlikely that there is a meaningful difference between the two cereals in cholesterol modification. However, as yet there are insufficient data to determine a dose-response relationship for barley $\beta$-glucan.

Health claims exist in the USA for oat and barley $\beta$-glucans and in Europe for $\beta$-glucans and maintenance of healthy cholesterol levels ${ }^{(57,58)}$ and for oat $\beta$-glucan and barley glucan for cholesterol reduction ${ }^{(54,59)}$. In order to carry the health claim in Europe, foods must meet the condition that $3 \mathrm{~g} \beta$-glucans per $\mathrm{d}$ from oats, oat bran, barley, barley bran, or from mixtures of non-processed or minimally processed $\beta$-glucans, should be contained in one or more servings. To achieve this level of $\beta$-glucan intake, a typical serving of cereals required is about $84 \mathrm{~g} / \mathrm{d}$. In practice this is difficult to achieve and realistically half of this amount could be consumed in a single meal at, say, breakfast.

Cereals, particularly whole-grain cereals, have been associated with a lower incidence of CHD or coronary death. However, the evidence is largely provided by epidemiological studies and the mechanisms of action uncertain; consequently, whether cholesterol reduction is of significance, over and above the contribution made by viscous fibre components of whole grains, is not clear ${ }^{(60)}$. In a meta-analysis of seven prospective cohort studies with quantitative measures of dietary whole grains and clinical cardiovascular outcomes it was shown that a greater whole-grain intake (pooled average 2.5 servings $v .0 \cdot 2$ servings/d) was associated with a $21 \%$ lower risk of CVD events (OR 0.79; 95\% CI 0.73, 0.85) ${ }^{(61)}$.

Viscous fibre in the form of pectins has a recognised blood cholesterol-lowering effect ${ }^{(52,62)}$. Pectins are linear chains of $\alpha-1-4$-galacturonic acid units with side chains including galacturonic and glucuronic acids; they are viscous and water-soluble fibres found in fruits and vegetables. By reference to two meta-analyses, the most recent of which included seven studies ( $n 277$ subjects), a statistically significant effect of pectins on total and LDL-cholesterol at intakes of $2 \cdot 2-9 \mathrm{~g} / \mathrm{d}$ was reported. There was also a significant dose-response relationship between the intake of soluble fibre (including pectins) and total and LDL-cholesterol lowering, but no significant dose-response relationship for HDL-cholesterol and $\mathrm{TAG}^{(52)}$. It was estimated that $1 \mathrm{~g}$ pectins/d produced significant changes in total and LDL-cholesterol of -0.07 (95\% CI $-0.117,-0.022)$ and -0.05 (95\% CI -0.087 , -0.022 ) $\mathrm{mmol} / 1$, respectively (both $P<0.05$ ). It was suggested that in order to make a claim relating to the cholesterol effect, foods should provide at least $6 \mathrm{~g}$ pectins/d in one or more servings ${ }^{(62)}$.

Another polysaccharide component for which an association between the maintenance of LDL-cholesterol and its consumption exists is chitosan ${ }^{(63)}$. The EFSA assessed evidence relating this polymer of $\beta$-1-4-linked D-glucosamine and $N$-acetyl-D-glucosamine, which is a component of the exoskeleton of crustaceans and the cell walls of fungi. They suggested that the evidence indicated a small, but statistically significant effect on the reduction of both total (combining five studies) and LDL-cholesterol (combining two studies) concentrations, with no effect observed on HDL-cholesterol. The Panel suggested that in order to have an effect on blood lipids, $3 \mathrm{~g}$ chitosan/d should be consumed. The mechanism by which chitosan is presumed to exert the claimed effect is far from conclusive, but it was suggested that it binds to negatively charged lipids and reduces their gastrointestinal uptake ${ }^{(63)}$

\section{Tree nuts}

Initially data demonstrating an association between tree nut intake and CHD were derived largely from epidemiological evidence. A pooled analysis of four US epidemiological studies showed that subjects in the highest intake group for nut consumption had an approximately 35\% reduced risk of CHD incidence ${ }^{(64)}$. There was speculation as to the actual mechanism(s) involved and it has been suggested that a lipid-lowering effect, involving total and LDL-cholesterol, may be the key mechanism involved. However, the level of blood lipid reduction tends to be greater than that predicted from the fatty acid composition of nuts. For example, in an analysis of seventeen RCT, it was demonstrated in the results from ten of these studies that nuts had a greater lipid-lowering effect than would have been predicted from their fatty acid composition alone $^{(64)}$. The average predicted reduction in LDL-cholesterol for the seventeen studies was $0.23 \mathrm{mmol} / 1$ and the measured reduction $0 \cdot 29 \mathrm{mmol} / \mathrm{l}$. It is suggested that nut protein, or some component thereof, may be responsible from this greater than predicted response. In a systematic review of studies that examined the relationship between the intake of nuts and their effect on blood lipids, it was found that in three almond (intake $50-100 \mathrm{~g} / \mathrm{d}$ ), two groundnut $(35-68 \mathrm{~g} / \mathrm{d})$, one pecan nut $(72 \mathrm{~g} / \mathrm{d})$ and four walnut $(40-84 \mathrm{~g} / \mathrm{d})$ studies that the decreases in total cholesterol were between 2 and $16 \%$ and those in LDL-cholesterol were between 2 and 19\%, compared with subjects consuming control diets ${ }^{(65)}$.

A further meta-analysis of five RCT ( $n$ 142) conducted specifically with almonds, where intake was $25-168 \mathrm{~g} / \mathrm{d}$, demonstrated a reduction in total cholesterol of $0 \cdot 18$ (95\% CI $-0.34,-0.02) \mathrm{mmol} / \mathrm{l}(P<0.05)$ and LDL-cholesterol of $0.15(95 \% \mathrm{CI}-0 \cdot 29,0 \cdot 00) \mathrm{mmol} / \mathrm{l}(\mathrm{NS})^{(66)}$.

Studies conducted with walnuts were reviewed and random-effects meta-analysis of blood lipid outcomes was conducted in thirteen RCT $(n 365)^{(67)}$. In these RCT, walnuts provided $10-24 \%$ of total energy intake. Diets supplemented with walnuts resulted in a significant reduction in total and LDL-cholesterol of $0 \cdot 27$ and $0.24 \mathrm{mmol} / 1$, respectively (both $P<0.001$ ), while 
HDL-cholesterol and TAG were not significantly different. A further recent small study also indicated an effect on LDL-cholesterol, over and above that predicted from the composition of nuts, either walnuts or almonds, and virgin olive oil ${ }^{(68)}$.

In 2003 in the USA, a Qualified Health Claim was approved, which identified that the data suggested, but did not prove, that the intake of $1.5 \mathrm{oz}(42 \mathrm{~g})$ nuts/d may reduce the risk of heart disease. Usual intakes in both the USA and Europe fall short of this, where intakes are 21 and $31 \mathrm{~g} / \mathrm{d}$, respectively ${ }^{(69)}$. The important factor with nuts is that they are largely consumed as a snack and, as such, offer a healthy alternative to high-fat micronutrientpoor snacks that furthermore can make a significant contribution to cholesterol reduction and improve the fat quality by replacing about $5-8 \mathrm{~g}$ SFA with MUFA per portion.

\section{Other foods or beverages that may modify blood lipids}

A masterly analysis of the effects of flavonoids on heart disease risk factors was conducted in 2008 where data from 133 RCT were evaluated ${ }^{(44)}$. Within this review, sub-analysis of the effects of either chocolate/cocoa or green tea flavonoids on blood lipids (LDL) was conducted. Four studies were pooled for green tea $(n$ 378) and five ( $n$ 214) for chocolate flavonoids. The resulting reduction in LDL-cholesterol was significant for green tea $(-0.23$ $(95 \% \mathrm{CI}-0.34,-0 \cdot 12) \mathrm{mmol} / \mathrm{l})$, but not for chocolate flavonoids $(-0.04(95 \% \mathrm{CI}-0.21,0.13) \mathrm{mmol} / \mathrm{l})$. While the RCT data for green tea look promising, further studies are needed to confirm the effect on blood lipids and when data were submitted to the EFSA for a health claim, an association with lipid lowering was not established ${ }^{(70)}$. It seems likely that the beneficial effect that chocolate flavonoids may have on CHD risk is mediated through effects on blood pressure, not cholesterol.

Two meta-analyses, both retaining twenty-eight RCT, studied the effect on blood lipids where the dietary intervention was flaxseed, either whole or its lignan component ${ }^{(71,72)}$. Flaxseed interventions reduced total and LDL-cholesterol by $0.10(95 \% \mathrm{CI}-0.20,0.00)$ and 0.08 (95\% CI $-0 \cdot 16,0 \cdot 00) \mathrm{mmol} / \mathrm{l}$, respectively. No significant changes were found in the concentrations of HDL-cholesterol and TAG. The cholesterol-lowering effects were more apparent in females (particularly postmenopausal women) and those with high initial cholesterol concentrations. The authors concluded that while total cholesterol and LDL-cholesterol were reduced, further studies are needed to determine the efficiency of flaxseed on lipid profiles in men and premenopausal women. Flaxseed is a rich source of ALA, itself the subject of an assessment by the EFSA to evaluate its effect on blood lipids. It was concluded that a relationship was established between the intake of ALA and the maintenance of blood cholesterol concentrations. In order to bear the claim a food should contain at least $15 \%$ of the proposed labelling reference intake value of $2 \mathrm{~g} \mathrm{ALA} / \mathrm{d}^{(73)}$. This quantity of ALA can be found in approximately $2-3 \mathrm{~g}$ flaxseed.

Other legumes can be effective in cholesterol reduction, as indicated in a systematic review of the literature where 140 relevant reports were identified, of which ten RCT ( $n$ 268) were selected as being suitable for metaanalysis $^{(74)}$. A non-soya legume diet was compared with control, for a minimum duration of 3 weeks and changes in blood lipid reported. Pooled mean net change in total cholesterol for those consuming a legume diet compared with control was $-0.31(95 \% \mathrm{CI}-0.42,-0 \cdot 19) \mathrm{mmol} / \mathrm{l}$ and mean net change in LDL-cholesterol was $-0 \cdot 21$ (95\% CI - 0.30, - 0.12) mmol/1.

Garlic has many claimed health effects; in order to establish if there are quantifiable benefits on blood lipids, a meta-analysis was conducted of thirteen RCT $\left(n\right.$ 1056) ${ }^{(75)}$. In this analysis the inclusion of garlic did not result in any significant differences in all outcome measures examined, when compared with placebo. The effects on total and LDL-cholesterol were -0.04 (95\% CI $-0.15,0.07)$ and $-0.01(95 \% \mathrm{CI}-0.10,0.11) \mathrm{mmol} / \mathrm{l}$, respectively; there were no marked differences in HDL-cholesterol, TAG and apoB. In a second meta-analysis, twenty-nine trials were pooled and the effect of garlic on blood lipids reported. Garlic was found to significantly reduce total cholesterol by $-0.19(95 \% \mathrm{CI}-0.33,-0.06) \mathrm{mmol} / \mathrm{l}$ and TAG by $-0 \cdot 11(95 \% \mathrm{CI}-0 \cdot 19,-0 \cdot 06) \mathrm{mmol} / \mathrm{l}$, but had no significant effect on LDL- or HDL-cholesterol. There was a moderate degree of statistical heterogeneity in both meta-analyses, indicating a need for further studies to improve the confidence of this finding. Recently it has been suggested that garlic can affect several cardiovascular risk factors, not just lipoprotein modification, and may have important antioxidant and antiplatelet functions as well as inhibition of LDL uptake ${ }^{(76)}$.

\section{Contribution that specific food combinations can make to blood lipid modification}

Data relating to the cholesterol-lowering effect of single individual foods and food ingredients have been summarised, but a key question remains to be addressed: to what extent are the reductions in cholesterol additive when these food components are combined in the diet? Evidence provided by the 'portfolio diet' studies, where multiple changes to the diet have been made, has been reviewed to gain an understanding of this aspect.

\section{Portfolio diets}

To identify such studies, the Medline search undertaken used the specific search term 'portfolio diet'. From this, and a hand search of identified papers, eighteen 'portfolio' studies were identified, of which eleven were retained for further examination ${ }^{(11,12,77-85)}$. Excluded studies were those that did not measure blood lipids ${ }^{(86-91)}$, or were 
duplicates of other reports ${ }^{(92)}$. The oldest study identified in this series makes only two dietary changes, the introduction of soya protein and viscous fibre; information related to it has been detailed separately from the main portfolio diet studies, but it is useful in gaining an understanding of the extent to which the changes promoted by these foods are additive ${ }^{(85)}$. A summary of the retained studies and the dietary modifications made is detailed in Table 1.

There are 656 subjects that have participated in 'portfolio studies', approximately half of whom are men and half are postmenopausal women. Study duration was from 4-80 weeks. Studies have been conducted in both a metabolic setting (short-term clinical efficacy studies) with virtually all foods supplied and in community-based studies of $\geq 6$ months' duration, where free-living subjects are given dietary advice to help them adopt a portfolio diet.

Typically, the portfolio diets contain per $1000 \mathrm{kcal}$ (4.18 MJ): $1 \mathrm{~g}$ plant stanols or sterols, $16-23 \mathrm{~g}$ soya protein, 8-10 g viscous fibre (generally from oats, barley, psyllium and okra) and 16-23g nuts, usually almonds or a combination of tree nuts and groundnuts. Typical total energy intake is about $2500 \mathrm{kcal}(10.5 \mathrm{MJ}) / \mathrm{d}$ except in the weight-loss study, where it is $2000 \mathrm{kcal}(8 \cdot 4 \mathrm{MJ}) / \mathrm{d}^{(79)}$. A single study has evaluated the effect of adding MUFA to this combination of foods ${ }^{(12)}$. The diets are generally low or very low in SFA and the emphasis is on plant foods, with many of the interventions being either vegan or vegetarian.

The predicted reduction in cholesterol for each of these components has been calculated for a 'reasonable' daily intake of that food component as proposed by the portfolio diet and, in many cases, this amount consumed is markedly less than the quantity from which the effect on LDL-cholesterol was originally derived. Where this occurs, it has been assumed that a dose-response relationship exists between the amount of food or food ingredient intake and cholesterol lowering and a pro rata response calculated (see Table 2). This assumption is known to be valid and a dose-response relationship exists for $\beta$-glucans from oats and cholesterol reduction ${ }^{(58)}$, and similarly for MUFA from a variety of sources ${ }^{(18)}$. However, it is rather more contentious as to whether such a relationship exists for soya protein, where a dose-response relationship was reported in one analysis ${ }^{(37)}$ and not in others ${ }^{(38,43)}$. Nevertheless, despite these weaknesses, the data in Table 2 demonstrate that each single dietary intervention can have a modest effect on LDL-cholesterol and that these effects are biologically plausible. When the predicted cholesterol lowering for each component part of the portfolio diet is added together, the overall predicted reduction in LDL-cholesterol is about 33\%.

The extent of cholesterol modification associated with each of the 'portfolio diet' trials is detailed in Table 3. Where there was a control group, often a low-fat-diet, included in the study, the reported LDL-cholesterol reduction in the treatment group is over and above that reported for the control, i.e. a net effect. Where there was no control group, and in all studies where measures of LDL-cholesterol are taken at intervals, the value recorded for the longest period on trial is reported.

From Table 3, it can be seen that the reported reduction in LDL-cholesterol is close to the predicted value of about $33 \%$ in two studies, both of which were simple interventions of short duration (approximately 4 weeks) with no control group, where the reduction reported was 30 and $29 \%$, respectively ${ }^{(11,84)}$. Longer-term intervention studies ( $>6$ months) with a control group generally result in a reduction of LDL-cholesterol, approximately half of the predicted value, at about $15 \%^{(78,80,81)}$. One of the main factors responsible for this lower rate appears to be a reduction in compliance. In the short-term metabolic studies compliance is typically $>90 \%{ }^{(12,78)}$, whereas compliance measured in the 80-week study was 62, 53, 68 and $67 \%$ for soya protein, viscous fibre, almonds and plant sterol and stanols components, respectively ${ }^{(80)}$. Overall compliance with the 'portfolio diet' was typically about $60 \%$, but during a period when plant sterols or stanols were removed from the diet, compliance dropped to $45 \%{ }^{(80)}$. Attempts to improve compliance by more intensive dietary counselling, increasing counselling sessions from two to seven, had little overall effect on compliance although dietary adherence was directly associated with LDL-cholesterol reduction ${ }^{(78)}$. From the studies it appears that it is most difficult to comply with the target viscous fibre intake and perhaps easiest to comply with the target plant sterol and stanols and nuts intake.

Perhaps this is not too surprising when considered from a practical perspective, as generally foods providing plant sterols or stanols or soya protein are simple exchanges and easy to include in the diet, for example, replacing a pot of dairy yoghurt with a pot of soya or plant stanol or sterol equivalent, or replacing dairy milk with soya milk. Almonds or tree nuts can be provided to study volunteers as snack packets; these, too, are easy to accommodate in the diet as convenient replacements for higher-fat, -salt and -sugar snacks. However, introducing viscous fibres into the diet may necessitate changes to a number of dietary components to provide a balanced meal and require a fundamentally different approach to the diet. Where MUFA were included in the diet this was achieved by the addition of high-oleic sunflower-seed oil to the diet. Both high-oleic sunflower-seed and rapeseed are attractive salad oils that have the added advantage of being stable during many food processes and, as such, are suitable alternatives to fats high in TFA and SFA for a variety of food manufacturing purposes ${ }^{(93)}$.

\section{Mechanisms of action}

Clearly, while compliance with the portfolio regimen is a significant factor is assessing whether the component parts of the diet are genuinely additive, an understanding 


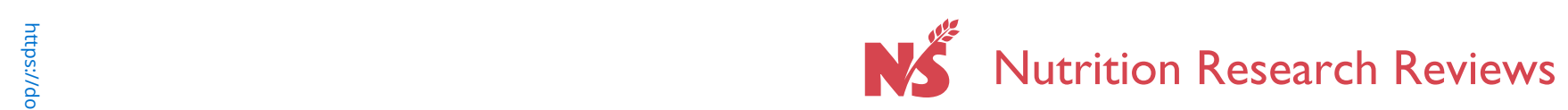

Table 1. Intake of specific foods that constitute component parts of 'portfolio diets' in trials identified by the present review

\begin{tabular}{|c|c|c|c|c|c|}
\hline Reference & $\begin{array}{l}\text { Plant stanols } \\
(\mathrm{g} / 1000 \mathrm{kcal})^{*}\end{array}$ & $\begin{array}{c}\mathrm{SP} \\
(\mathrm{g} / 1000 \mathrm{kcal})^{*}\end{array}$ & $\begin{array}{l}\text { Viscous fibres } \\
(\mathrm{g} / 1000 \mathrm{kcal})^{*}\end{array}$ & $\begin{array}{l}\text { Tree nuts or almonds } \\
(\mathrm{g} / 1000 \mathrm{kcal})^{*}\end{array}$ & Diet comments \\
\hline Jenkins et al. (2011) $)^{(78)}$ & 0.94 & $22 \cdot 5$ & $9 \cdot 8$ & $\begin{array}{l}22.5 \\
\text { Tree nuts and groundnuts }\end{array}$ & $\begin{array}{l}\text { Peas, beans and lentils intake encouraged } \\
\text { Control low-fat diet }\end{array}$ \\
\hline Jenkins et al. (2010) $)^{(12)}$ & $1 \cdot 0$ & $20 \cdot 0$ & $10 \cdot 3$ & $\begin{array}{l}21.5 \\
\text { Almonds }\end{array}$ & $\begin{array}{l}\text { 1-month run-in on very-low-fat diet, then } \\
\text { high- } v \text {. low-MUFA portfolio diets compared. } \\
\text { CHO at } 13 \% \text { energy replaced with MUFA } \\
\text { from high-oleic sunflower-seed oil; } 13 \\
\text { v. } 26 \% \text { energy from MUFA }\end{array}$ \\
\hline Jenkins et al. (2009) $)^{(79)}$ & 0 & About 18 & $3-3.5$ & $\begin{array}{l}\text { Nuts provided } 20.8 \mathrm{~g} \text { fat } \\
43.5 \% \text { energy from fat } \\
\text { Mixture of nuts }\end{array}$ & $\begin{array}{l}\text { Control diet: } 2000 \mathrm{kcal}^{\star} \text { lacto-ovo-vegetarian } \\
\text { diet, } 58 \% \text { energy from } \mathrm{CHO} \text { and } \\
25 \% \text { energy from fat } \\
2000 \mathrm{kcal}^{*} \text { Eco-Atkins diet: } 26 \% \text { energy from } \\
\mathrm{CHO}, 31 \% \text { energy from protein, } 43 \% \\
\text { energy from fat } \\
\text { Both groups lost } 4 \mathrm{~kg} \text { in weight }\end{array}$ \\
\hline Jenkins et al. $(2008)^{(80)}$ & $1 \dagger$ & $22 \cdot 5$ & 10 & $\begin{array}{l}23 \\
\text { Almonds }\end{array}$ & No control group \\
\hline Jenkins et al. (2006) $)^{(81)}$ & 1 & $22 \cdot 5$ & 10 & $\begin{array}{l}23 \\
\text { Almonds }\end{array}$ & $\begin{array}{l}\text { No control group } \\
\text { Subjects encouraged to eat other plant } \\
\text { proteins and fibre }\end{array}$ \\
\hline Jenkins et al. (2005) $)^{(77)}$ & 1 & $21 \cdot 4$ & 10 & $\begin{array}{l}14 \\
\text { Almonds }\end{array}$ & $\begin{array}{l}\text { Very-low-SFA diet control, second } \\
\text { comparison with statin }\end{array}$ \\
\hline Lamarche et al. (2004) & 1 & $22 \cdot 7$ & $8 \cdot 2$ & $\begin{array}{l}15 \\
\text { Almonds }\end{array}$ & Very-low-fat SFA diet \\
\hline Jenkins et al. $(2003)^{(83)}$ & 1 & $21 \cdot 4$ & $9 \cdot 8$ & $\begin{array}{l}14 \\
\text { Almonds }\end{array}$ & $\begin{array}{l}\text { Very-low-fat SFA diet based on whole } \\
\text { wheat and low-fat dairy products } \\
\text { Second comparison included added statin }\end{array}$ \\
\hline Jenkins et al. (2003) $)^{(84)}$ & $1 \cdot 2$ & $16 \cdot 2$ & $8 \cdot 3$ & $\begin{array}{l}16 \cdot 6 \\
\text { Almonds }\end{array}$ & $\begin{array}{l}\text { Vegan 'portfolio diet' compared with } \\
\text { lacto-ovo-vegetarian NCEP } 2 \text { diet }\end{array}$ \\
\hline Jenkins et al. (2002) $)^{(11)}$ & 1 & 23 & 9 & 0 & No control, very-low-SFA 'portfolio diet' \\
\hline
\end{tabular}

SP soya protein; CHO, carbohydrate; NCEP, National Cholesterol Education Program.

tIncluded study period of 10 weeks without plant sterols. Note that this is an extension to Jenkins et al. ${ }^{(81)}$. 
Table 2. Relative contribution that specific foods can make to blood lipid modification

\begin{tabular}{|c|c|c|c|c|c|}
\hline \multirow[b]{2}{*}{ Food or component } & \multirow[b]{2}{*}{ Amount $(\mathrm{g} / \mathrm{d})$} & \multirow{2}{*}{$\begin{array}{l}\text { Effect on } \\
\text { LDL-cholesterol (\%) }\end{array}$} & \multicolumn{2}{|c|}{$\begin{array}{l}\text { Approximate estimated reduction in LDL when } \\
\text { used at typical inclusion rate in 'portfolio diet' }\end{array}$} & \multirow[b]{2}{*}{ Reference } \\
\hline & & & $\%$ & $\mathrm{mmol} / \mathrm{l}$ & \\
\hline Saturated fat & $<7 \%$ energy & 10 & 4 & 0.15 & 10 \\
\hline Plant sterols & $1.5-1.9$ & 8.5 & 8.7 & 0.35 & 27 \\
\hline Plant stanols & $2 \cdot 0-2 \cdot 4$ & 8.9 & & & \\
\hline Soya protein & 25 & $4 \cdot 5-7$ & $5 \cdot 5$ & 0.22 & $37-46$ \\
\hline \multicolumn{6}{|l|}{ Soluble fibre } \\
\hline Mixed viscous fibres & Up to 10 & $1.3 \% / \mathrm{g}$ & 8 & $0.35-0.50$ & $52,54,62$ \\
\hline Oats or barley $\beta$-glucan & 3 & $3.5-5$ & 5 & 0.2 & 52 \\
\hline Psyllium & $9-10$ & $0.72 \% / g$ & $7 \cdot 2$ & 0.3 & 10 \\
\hline Tree nuts & & & 7 & 0.29 & 64 \\
\hline Almonds & $25-168$ & 3.75 & 3.75 & 0.15 & 66 \\
\hline Inclusion of MUFA & 10 & $5 \cdot 8$ & 7.5 & 0.32 & 18 \\
\hline $\begin{array}{l}\text { Theoretical additive total from } \\
\text { 'portfolio' components }\end{array}$ & & & $33 \cdot 2$ & $1 \cdot 36$ & \\
\hline Plus MUFA & & & 40 & $1 \cdot 7$ & \\
\hline Non-soya legumes & & About 5 & NA & NA & 74 \\
\hline Flaxseed & $2-3 g$ & About 3 & NA & NA & 71,72 \\
\hline Body weight & Lose $4.5 \mathrm{~kg}$ & 5 & NA & NA & 10 \\
\hline Dietary cholesterol & $<200 \mathrm{mg} / \mathrm{d}$ & 5 & NA & NA & 10 \\
\hline
\end{tabular}

NA, not available.

of the mechanisms of action by which each component in the diet is thought to act and the identification of any potential incompatibility between them are also important.

An inhibition of intestinal absorption of both dietary and endogenous cholesterol is the mechanism by which plant sterols and sterols are thought to exert their effect, although the molecular mechanisms involved are not fully resolved. In simple terms, the presence of increased quantities of plant sterols or sterols competes with cholesterol for micellar solubility, therefore lowering the amount of cholesterol available for absorption by intestinal mucosal cells ${ }^{(94,95)}$.

Despite markedly different structure and composition, it has been suggested that viscosity rather than quantity of soluble dietary fibre predicts its cholesterol-lowering effect $^{(96)}$. Furthermore, it has been reported that no major differences exist between the four different types of water-soluble fibres ( $\beta$-glucan, psyllium, pectin and guar gum) in the extent to which they reduce cholesterol ${ }^{(52)}$; thus it is proposed that there is a common underlying mechanism, namely that water-soluble fibre slows the reabsorption of particular bile acids and as a result hepatic conversion of cholesterol into bile acids increases, resulting in turn in an increased LDL uptake by the liver ${ }^{(97)}$. Certainly with regard to $\beta$-glucan there is good evidence that its mechanism of action is related to viscosity; with viscosity in the small intestine determined by the concentration, molecular weight and solubility of the $\beta$-glucans ${ }^{(54)}$. With pectins it is their molecular size and degree of esterification that have been shown to be important determinants of effectiveness ${ }^{(98)}$. Nevertheless, the core cholesterol-lowering mechanisms for soluble fibres seem to involve reabsorption of bile acids, increased synthesis of bile acids from cholesterol and reduced circulating LDL-cholesterol concentrations.

The actual mechanism involved in the cholesterol-lowering process when soya protein is incorporated in the diet is less clear. Some researchers suggest it is the protein itself, in particular the $7 \mathrm{~S}$ globulin, that up-regulates the activity of the LDL receptors ${ }^{(99)}$, while others also suggest a role for the soya isoflavones associated with the protein ${ }^{(100)}$. However, isolated soya isoflavones have generally not been found to reduce cholesterol ${ }^{(101)}$. In all probability the major mechanism(s) by which cholesterol is lowered is largely related to the soya protein component per se, but as the isoflavones in their natural form are integrally linked to the protein, they too may be important in determining effectiveness. Certainly, soya protein processed in a manner to deplete the isoflavone content generally has a reduced cholesterol-lowering capacity ${ }^{(42)}$.

As recently concluded by the EFSA, the mechanism by which tree nuts, or more specifically walnuts, affect blood cholesterol was attributed to their content of MUFA and PUFA ${ }^{(102)}$. This conclusion was made despite indications from the data detailed previously; nonetheless, in weighing the evidence it concluded that the consumption of walnuts did not have an effect on blood LDL-concentrations beyond what could be expected from their fatty acid composition.

The added value of including MUFA in the diet and their effect on blood lipid profile was also shown in a single 'portfolio diet' study that incorporated a high-oleic sunflower-seed oil ${ }^{(12)}$. This study achieved the joint objectives of reducing LDL-cholesterol levels and improving HDL-cholesterol levels, thus demonstrating the value of improving fat quality of the diet, as well as introducing cholesterol-lowering foods into the diet. 


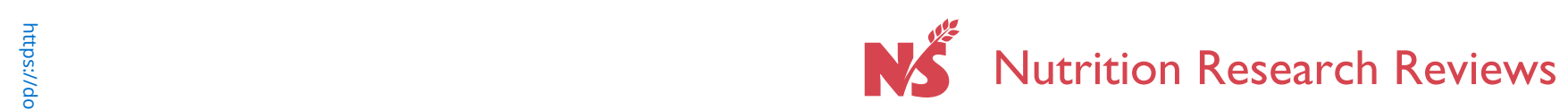

Table 3. Study characteristics and the effect on blood cholesterol and ratios of total or LDL-cholesterol:HDL-cholesterol where 'portfolio diets' adopted

\begin{tabular}{|c|c|c|c|c|c|c|c|c|c|c|}
\hline \multirow[b]{2}{*}{ Author } & \multirow[b]{2}{*}{$\begin{array}{l}\text { Study length } \\
\text { and design }\end{array}$} & \multirow{2}{*}{$\begin{array}{c}\text { Treatment } \\
\text { participants }(n)\end{array}$} & \multicolumn{2}{|c|}{ Reduction in LDL } & \multicolumn{2}{|c|}{ Change in HDL } & \multicolumn{2}{|c|}{ Improvement (\%) } & \multicolumn{2}{|c|}{$P$} \\
\hline & & & $\%$ & $P$ & $\mathrm{mmol} / \mathrm{l}$ & $P$ & Total:HDL & LDL:HDL & Total:HDL & LDL:HDL \\
\hline \multirow[t]{2}{*}{ Jenkins et al. $(2011)^{(78)}$} & 6 months, $\mathrm{RCP}$ & 351 & $15 \cdot 2^{*}$ & $\leq 0.05$ & & NS & $7 \cdot 8$ & NA & 0.006 & NA \\
\hline & & $137 \mathrm{M} / 214 \mathrm{PF}$ & $14.5 \dagger$ & $\leq 0.05$ & & NS & $9 \cdot 6$ & NA & 0.004 & NA \\
\hline \multirow[t]{2}{*}{ Jenkins et al. $(2010)^{(12)}$} & 4 weeks, $\mathrm{RP}$ & 24 & $22 \cdot 0 \ddagger$ & NA & 0.13 & NA & NA & NA & & \\
\hline & & $17 \mathrm{M} / 7 \mathrm{~F}$ & $1 \cdot 1 \S$ & $\begin{array}{l}\text { High } v \text {. low } \\
\text { MUFA: NS }\end{array}$ & 0.12 & 0.003 & $5 \cdot 4$ & $6 \cdot 3$ & 0.03 & 0.03 \\
\hline Jenkins et al. $(2009)^{(79)}$ & 1 month, RCP & $\begin{array}{l}44 \\
18 \mathrm{M} / 26 \mathrm{PF}\end{array}$ & $6 \cdot 8$ & 0.002 & & NS & $5 \cdot 6$ & $3 \cdot 4$ & 0.03 & 0.02 \\
\hline \multirow[t]{2}{*}{ Jenkins et al. (2008) ${ }^{(80)}$} & 80 weeks, RP & 42 & $15 \cdot 4 \|$ & $<0.001$ & & NS & $12 \cdot 3$ & $18 \cdot 3$ & 0.001 & 0.001 \\
\hline & & $19 \mathrm{M} / 23 \mathrm{PF}$ & $9.00 \emptyset$ & $<0.001$ & & NS & $8 \cdot 8$ & $10 \cdot 9$ & $<0.001$ & $<0.001$ \\
\hline Jenkins et al. (2006) $)^{(81)}$ & 1 year, IT & $\begin{array}{l}66 \\
31 \mathrm{M} / 35 \mathrm{PF}\end{array}$ & $13 \cdot 6$ & $<0.0001$ & 0.04 & 0.026 & $12 \cdot 6$ & $15 \cdot 4$ & $<0.0001$ & $<0.0001$ \\
\hline Jenkins et al. (2005) ${ }^{(77)}$ & 4 weeks, RCX & $\begin{array}{l}34 \\
20 \mathrm{M} / 14 \mathrm{PF}\end{array}$ & 19.9 (net) & $<0.001$ & & NS & $17 \cdot 0$ & $25 \cdot 0$ & $<0.001$ & $<0.001$ \\
\hline Lamarche et al. (2004) ${ }^{(82)}$ & 4 weeks, IT & $\begin{array}{l}12 \\
6 \mathrm{M} / 6 \mathrm{PF}\end{array}$ & $29 \cdot 8$ & $<0.0001$ & & NS & NA & NA & NA & NA \\
\hline Jenkins et al. $(2003)^{(83)}$ & 1 month, RCP & $\begin{array}{l}46 \\
25 \mathrm{M} / 21 \mathrm{PF}\end{array}$ & 21.4 (net) & $<0.005$ & & NS & $17 \cdot 1$ & $25 \cdot 1$ & $<0.005$ & $<0.005$ \\
\hline Jenkins et al. $(2003)^{(84)}$ & 4 weeks, RCP & $\begin{array}{l}24 \\
16 \mathrm{M} / 9 \mathrm{PF}\end{array}$ & 22.9 (net) & $<0.001$ & & NS & $20 \cdot 8$ & $30 \cdot 0$ & $<0.001$ & $<0.001$ \\
\hline Jenkins et al. (2002) $)^{(11)}$ & 1 month, IT & $\begin{array}{l}13 \\
7 \mathrm{M} / 6 \mathrm{PF}\end{array}$ & $28 \cdot 7$ & $<0.05$ & & NS & $20 \cdot 9$ & $26 \cdot 0$ & $<0.05$ & $<0.05$ \\
\hline
\end{tabular}

RCP, randomised controlled parallel study; M, male; PF, postmenopausal female; NA, not available; RP, randomised parallel study; F, female; IT, single-phase intervention trial (comparison with baseline); RCX, randomised controlled cross-over trial.

* Controndard counselling two visits/6 months.

† Intensive counselling seven visits/6 months.

‡Difference compared with baseline.

$\S$ End of study high-MUFA portfolio compared with low MUFA.

II Plant sterols throughout study period. 
As to whether there are any conflicts or synergies between the modus operandi of the various components of the portfolio diet is less well understood. As the reported changes in blood lipids in short-term well-controlled portfolio-diet studies appear to be not too different from the value predicted from the sum of the individual components, there largely appears to be an additive effect. However, there is still a high degree of uncertainty with regard to the detailed mechanisms involved and, because of this, the degree of synergy can best be determined by looking at simple substitutions, made in a stepwise fashion, rather than in studies where multiple changes are made at the same time. Thus, well-conducted studies where only two component changes are made and each accessed independently, as well as together, provide a better insight to the extent of synergy or antagonism between the cholesterol-lowering foods ${ }^{(103)}$.

\section{Simple food combinations}

Long-term compliance with dietary intervention is crucial to effectiveness. What influences compliance is a huge subject in its own right, a key aspect of which is motivation that can vary widely among individuals. In a review of three studies investigating subjects' motivation to change their diet to match nutritional goals, all participants achieved a change in dietary intake over 1 week and met one nutritional goal ${ }^{(104)}$. However, it was much easier to substitute one item in the diet for another or reduce consumption of certain foods that contained or contributed a significant amount of fat, such as margarine and milk. In the short term dietary change may be relatively easy, but over the longer term availability of foods, especially snack foods, can make adherence difficult. Subjects in the Diet and Reinfarction Trial (DART) found it relatively easy to make one dietary alteration, but where two nutrients were involved it became more difficult ${ }^{(105)}$. In many respects the macronutrient content of the 'portfolio diet' closely resembles DART interventions, particularly the two interventions used in the OmniHeart studies, one of which was a protein-rich diet with about half the protein from plant sources and the second, a diet rich in unsaturated fat, predominantly MUFA ${ }^{(106)}$.

In considering effective food combinations for cholesterol modification and maximum compliance, it may therefore be more effective to restrict the number of changes to the diet and focus on making only two changes. Two pertinent dietary changes with a high level of compliance could result in substantial cholesterol lowering. There is a limited number of studies in the literature where changes have been made to two discrete cholesterol-lowering components, without significant manipulation of the background diet, and where the effect of each has been quantified separately and as a combination, necessary to establish the extent of synergy between the agents; see, for example, Theuwissen \& Mensink ${ }^{(103)}$ and Yoshida et $a l .{ }^{(107)}$. In a further study the effects of oats and soya protein were assessed independently and together, but after all subjects had complied with the macronutrient targets of an American Heart Association step 1 diet for 3 weeks ${ }^{(108)}$. Other studies report the effect of introducing two cholesterol-modification agents in the diet, but do not assess the effect of each independently; see, for example, the evaluation of soya drinks with plant sterol or stanols ${ }^{(109-111)}$. A summary of studies that report use of two of the cholesterol-lowering components detailed in the earlier sections is given in Table 4.

There is considerable variation in the quality of the studies detailed in Table 4; three studies were doubleblinded, six studies included a control and, of these, only three studies included a placebo intervention. Study duration was relatively short and varied between 3 weeks and 3 months. Three studies used plant stanol or sterolsoluble fibre combinations ${ }^{(103,107,112)}$, of which two determined the effect of the individual components, as well as the combination ${ }^{(103,107)}$.

From these studies it can be seen that the effects of introducing two food components into the diet are to a degree additive, although less than would have been predicted in respect of the plant stanol-oat $\beta$-glucan combination ${ }^{(103)}$. Specifically, the addition of plant stanol esters to $\beta$-glucan-enriched muesli significantly lowered LDLcholesterol concentrations by $4.4 \%$, less than the estimated change of approximately $8.5 \%$. The authors suggested that the lower response was due to the higher viscosity in the intestinal lumen produced by the $\beta$-glucan, which interfered with the absorption of plant stanols. As plant stanols reduce intestinal cholesterol absorption through competition for micellar incorporation and promote cholesterol efflux back into the intestinal lumen this may have been compromised, resulting in both reduced serum concentrations and lower efficacy of the plant stanols. Alternatively, higher intestinal viscosity may affect lipid emulsification and the hydrolysis of plant stanol esters to active free plant stanols released later in the intestinal tract and thus affect overall efficacy and absorption. A study in which a glucomannan-plant sterol combination was used also provides an insight to the mechanisms involved. In this study plasma lathosterol, a cholesterol precursor and an index of cholesterol synthesis, was determined $^{(107)}$. Plasma lathosterol concentrations were increased from baseline with plant sterol treatment, but not with glucomannan supplementation; furthermore the glucomannan-plant sterol combination resulted in decreased plasma lathosterol $(P<0.05)$, suggesting that glucomannan suppresses the compensatory increase of cholesterol synthesis by plant sterol intake ${ }^{(107)}$. In a study where mildly hypercholesterolaemic subjects consumed $\beta$-glucan with or without plant stanol esters, there was no significant effect on inflammatory parameters, nor were there changes in expression profiles of eighty-four genes involved in atherosclerosis metabolism when 
Table 4. Study characteristics and the effect on LDL- and HDL-cholesterol when two cholesterol-modifying components are introduced in the diet

\begin{tabular}{|c|c|c|c|c|c|c|c|}
\hline Author & Diet intervention & $\begin{array}{l}\text { Study length } \\
\text { and design }\end{array}$ & $\begin{array}{l}\text { Treatment } \\
\text { participants }(n)\end{array}$ & $\begin{array}{l}\text { Change (net) } \\
\text { in LDL }(\%)^{*}\end{array}$ & $P$ & $\begin{array}{l}\text { Change (net) } \\
\text { in } \mathrm{HDL}(\%)^{*}\end{array}$ & $P$ \\
\hline Cicero et al. (2002) $)^{(111)}$ & $\begin{array}{l}\text { Established baseline compared with soya drink (4:1): } 8 \mathrm{~g} \text { soya protein } \\
\quad+2 \mathrm{~g} \text { plant sterol/d }\end{array}$ & $120 \mathrm{~d}, \mathrm{IT}$ & 20 & $9 \cdot 6$ & $<0.05$ & $8 \cdot 2$ & NS \\
\hline Cicero et al. $(2004)^{(110)}$ & $\begin{array}{l}\text { Established baseline compared with soya drink ( } 4: 1): 8 \mathrm{~g} \text { soya protein } \\
\quad+2 \mathrm{~g} \text { plant sterol/d }\end{array}$ & $120 \mathrm{~d}, \mathrm{IT}$ & $\begin{array}{l}36 \\
18 \mathrm{M} / 18 \mathrm{~F}\end{array}$ & $11 \cdot 6+$ & $<0.05$ & $2 \cdot 2 \dagger$ & NS \\
\hline Jenkins et al. (1999) $)^{(85)}$ & $\begin{array}{l}\text { Simple combination of } 14.1 \mathrm{~g} \text { soya protein and } 7.6 \mathrm{~g} \text { viscous fibres } / \mathrm{d} \\
\text { compared with lacto-ovo-vegetarian diet }\end{array}$ & 1 month, $\mathrm{RCX}$ & $\begin{array}{l}31 \\
19 \mathrm{M} / 12 \mathrm{PF}\end{array}$ & $6 \cdot 4$ & $<0.001$ & & NS \\
\hline Lukaczer et al. (2006) ${ }^{(114)}$ & $\begin{array}{l}\text { Low-glycaemic index diet with } 30 \mathrm{~g} \text { soya protein and } 4 \mathrm{~g} \text { phytosterol/d } \\
\text { compared with American Heart Association step } 1 \text { diet }\end{array}$ & 12 weeks, RCP & $59 \mathrm{PF}$ & $\begin{array}{l}14 \cdot 6 \dagger \\
18 \cdot 0\end{array}$ & $<0.01$ & $\begin{array}{l}+5 \cdot 6 \dagger \\
+4 \cdot 8\end{array}$ & 0.05 \\
\hline Shrestha et al. $(2006)^{(112)}$ & Control cookies or cookies with $7.68 \mathrm{~g}$ psyllium and $2.6 \mathrm{~g}$ plant sterols $/ \mathrm{d}$ & 4 weeks, $\mathrm{RCX}, \mathrm{DB}$ & $\begin{array}{l}33 \\
11 \mathrm{M} / 22 \mathrm{~F}\end{array}$ & $9 \cdot 7$ & $<0.01$ & -0.05 & NS \\
\hline Theuwissen & Control $5 \mathrm{~g}$ wheat fibre or & 4 weeks, $\mathrm{RCX}, \mathrm{DB}$ & 43 & & & & \\
\hline \& Mensink $(2007)^{(103)}$ & $\begin{array}{l}5 \mathrm{~g} \text { oat } \beta \text {-glucan or } \\
5 \mathrm{~g} \text { oat } \beta \text {-glucan }+1.5 \mathrm{~g} \text { plant stanols } / \mathrm{d}\end{array}$ & & $20 \mathrm{M} / 23 \mathrm{~F}$ & $\begin{array}{l}5 \cdot 1 \\
9 \cdot 7\end{array}$ & $\begin{array}{l}<0.05 \\
<0.05\end{array}$ & $\begin{array}{l}-0.7 \\
-0.7\end{array}$ & $\begin{array}{l}\text { NS } \\
\text { NS }\end{array}$ \\
\hline Torres et al. (2009) $)^{(115)}$ & $\begin{array}{l}1 \text { month on low-SFA diet followed by } 2 \text { months on low-SFA diet }+25 \mathrm{~g} \\
\text { soya protein and } 15 \mathrm{~g} \text { soluble fibre/d }\end{array}$ & 3 months, IT & $\begin{array}{l}43 \\
20 \mathrm{M} / 23 \mathrm{~F}\end{array}$ & $20 \cdot 6 \ddagger$ & $<0.05$ & & \\
\hline Van Horn et al. $(2001)^{(108)}$ & $\begin{array}{l}\text { 3-week American Heart Association step } 1 \text { diet then control of oats } / \text { milk } \\
\text { or } 1.7 \mathrm{~g} \text { oats soluble fibre/milk protein } \\
20.8 \mathrm{~g} \text { soya protein/wheat } \\
0.9 \mathrm{~g} \text { oats soluble fibre } / 18.7 \mathrm{~g} \text { soya protein }\end{array}$ & 6 weeks, $\mathrm{RCP}$ & $127 \mathrm{PF}$ & $\begin{array}{l}5.7 \\
+0.2 \\
6.9\end{array}$ & $\begin{array}{l}<0.02 \\
\text { NS } \\
<0.02\end{array}$ & $\begin{array}{l}-1.7 \\
-0.6 \\
-0.6\end{array}$ & $\begin{array}{l}\text { NS } \\
\text { NS } \\
\text { NS }\end{array}$ \\
\hline Weidner et al. $(2008)^{(109)}$ & Control soya drink compared with $200 \mathrm{ml}$ soya drink $+1.6 \mathrm{~g}$ plant stanol & 8 weeks, RP, DB & $\begin{array}{l}50 \\
19 \mathrm{M} / 31 \mathrm{~F}\end{array}$ & $6.8 \dagger$ & $<0.05$ & $3 \cdot 1 \dagger$ & NS \\
\hline Yoshida et al. (2006) ${ }^{(107)}$ & $\begin{array}{l}\text { Control bars } \\
\text { Bars with } 1.8 \mathrm{~g} \text { plant sterols } / \mathrm{d} \\
\text { Bars with } 10 \mathrm{~g} \text { glucomannan } / \mathrm{d} \\
\text { Bars with } 1.8 \mathrm{~g} \text { plant sterols }+10 \mathrm{~g} \text { glucomannan } / \mathrm{d}\end{array}$ & 3 weeks, $\mathrm{RCX}$ & $\begin{array}{l}34 \\
18 \S \\
8 \mathrm{M} / 10 \mathrm{~F} \\
(16 \mathrm{~T} \mathrm{II}: 4 \mathrm{M} / 12 \mathrm{~F})\end{array}$ & $\begin{array}{l}5 \cdot 4 \\
13 \cdot 8 \\
21.8\end{array}$ & $\begin{array}{l}\text { NS } \\
<0.05 \\
<0.05\end{array}$ & $\begin{array}{l}0.6 \\
-5.0 \\
-8.5\end{array}$ & $\begin{array}{l}\text { NS } \\
\text { NS } \\
\text { NS }\end{array}$ \\
\hline
\end{tabular}

$\mathrm{IT}$, single-phase intervention trial (comparison with baseline); M, male; F, female; RCX, randomised controlled cross-over trial; RCP, randomised controlled parallel study; DB, double-blinded study; PF, postmenopausal female; RP, randomised parallel study; $T$ II, type 2 diabetics.

*Between treatment and control:

Within treatment, total cholesterol.

Data presented for non-diabetic subjects only. 


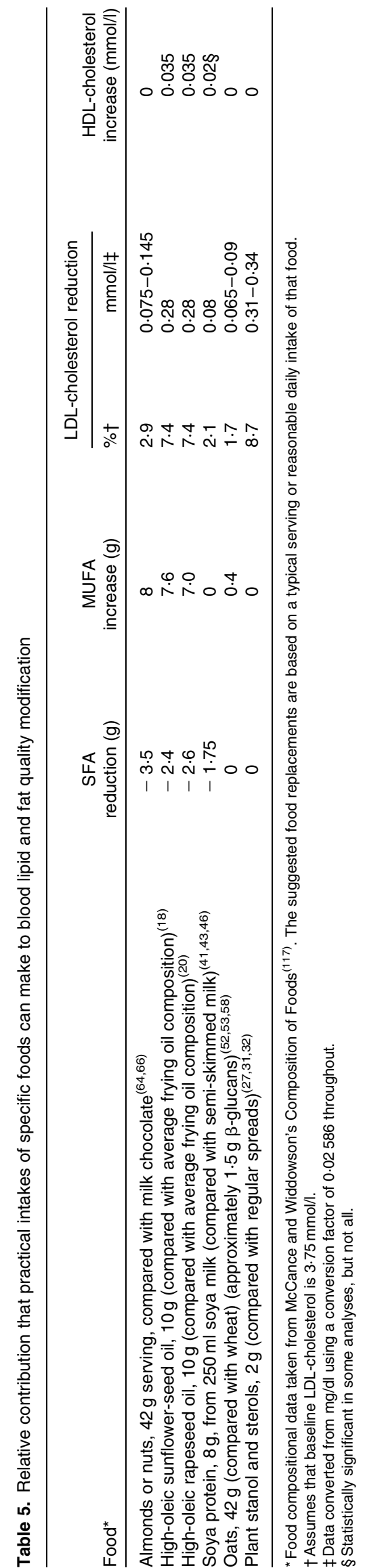

$\beta$-glucan was included in the diet and the expression of only three genes - ADFP (adipose differentiation-related protein), CDH5 (cadherin 5, type 2) and CSF2 (granulocyte-macrophage colony-stimulating factor 2) - changed after plant stanol ester consumption ${ }^{(113)}$.

It has also been suggested that the food matrix in which plant stanols or sterols are presented can influence their effectiveness $^{(32)}$. Four studies evaluated the effect of soya protein-plant stanol or sterol combinations and reported a LDL-cholesterol reduction of between 6.8 and $14 \cdot 6 \%{ }^{(109-111,114)}$. However, as only one of these studies included a control group, which was advice to follow an American Heart Association step 1 diet, there is neither the basis to assess the degree to which these changes were additive nor the effect of the food matrix.

Soya protein-soluble fibre combinations demonstrated an effect on cholesterol that is additive to some degree in the early study by Jenkins et $a l .{ }^{(85)}$, although there was little synergistic effect on LDL-cholesterol in a further well-controlled study ${ }^{(108)}$, but a greater effect in a less controlled study of longer duration ${ }^{(115)}$.

The extent to which these reported reductions in LDL-cholesterol is a reflection of the true additive nature of the dietary interventions and that could be predicted from each component, or good compliance, is not clear. The variable quality, relatively small size and limited duration of these studies make interpretation difficult.

Nevertheless, in practical situations, reductions in LDLcholesterol concentration of about $15 \%$ have been achieved in studies of 4-12 weeks' duration by both soya protein-plant sterol and viscous fibre-soya protein combinations $^{(110,111,114)}$, representing a significant benefit and reduction in coronary risk to those otherwise healthy subjects with mild hypercholesterolaemia.

When considering effective public health measures, reference to habitual diet could be made to select the interventions most likely to be effective for each individual. Identification of the most appropriate food or food component exchanges for an individual, by reference to a diet diary, improves the likelihood of success due to better compliance. In addition, by careful selection of the components involved, the joint objective of cholesterol improvement and improved fat quality in the diet could be achieved. Two relatively small dietary changes could typically result in a reduction in LDL-cholesterol of $5-15 \%$, sufficient to reduce coronary risk by $10-30 \%$ and make a meaningful contribution to public health ${ }^{(116)}$. Examples of the impact on both LDL-cholesterol and fat quality of the diet by including some of the previously discussed food or food component exchanges as replacements for less healthy frequently consumed foods and snacks are summarised in Table 5. 


\section{Conclusions}

There are a number of foods and food components for which good evidence, from well-conducted RCT, indicates an ability to significantly reduce LDL-cholesterol; typically the reduction is $3-9 \%$ compared with baseline when a single component is included in the diet. In the main, it appears that the combined effect of individual components is to some degree additive when used in simple combinations, although determination of the extent of this synergy is limited by the quality of some of the studies in the literature. Nevertheless, evidence exists that suggests that the introduction of two or more of these foods or food components into the diet, at their target level of intake and in a highly practical manner, can be achieved and results in a reduction of LDL-cholesterol of 5-15\%. As a public health measure, simple dietary changes can have a significant impact on cholesterol management in those with mild hypercholesterolaemia.

Where a 'portfolio diet' is adopted the extent of the LDLcholesterol reduction is much greater and up to $30 \%$ in short-term well-controlled studies where the foods are provided and $15 \%$ in community-based studies over periods of 6 months or more. Compliance with dietary change and, in particular, the challenge of multiple interventions influence the degree of effectiveness of the regimen. Consequently, careful consideration needs to be given to the appropriate food or food components combination for an individual in order to assist long-term compliance and effectiveness of the intervention. Furthermore, improving the fat quality of the diet by the introduction of unsaturated fat can also enhance blood lipid changes by helping to maintain or improve HDL-cholesterol concentrations. It is suggested that the future focus of cholesterol-lowering regimens needs to place emphasis not only on the effect of food components on LDL-cholesterol, but also the role they can play in improving fat quality.

\section{Acknowledgements}

The present review and its interpretation have been produced independently. This research received no specific grant from any funding agency in the public, commercial or not-for-profit sectors. The assistance of Katie Kennedy in assessing the macronutrient intake from portfolio diets is acknowledged.

There are no conflicts of interest. J. I. H. provides nutrition consultancy services to a wide cross-section of the food industry and food industry organisations.

\section{References}

1. Allender S, Scarborough P, Peto V, et al (2008) European Cardiovascular Disease Statistics http://www.bhf.org.uk/ idoc.ashx?docid=e4f82fee-58f0-4a51-8099-db9520123e24 \&version=-1 (accessed December 2011).
2. Reiner Z, Catapano AL, De Backer G, et al. (2011) ESC/EAS guidelines for the management of dyslipidaemias: the Task Force for the management of dyslipidaemias of the European Society of Cardiology (ESC) and the European Atherosclerosis Society (EAS). Eur Heart J 32, 1769-1818.

3. World Health Organization (2002) The World Health Report 2002; Reducing Risks, Promoting Healthy Life. WHO: Geneva.

4. Expert Panel on Detection, Evaluation, and Treatment of High Blood Cholesterol in Adults (2001) Executive summary of the third report of the National Cholesterol Education Program (NCEP) expert panel on detection, evaluation, and treatment of high blood cholesterol in adults (Adult Treatment Panel III). JAMA 285, 2486-2497.

5. Joint British Societies (2005) Guidelines on prevention of cardiovascular disease in clinical practice. Heart 91, $\mathrm{v} 1-\mathrm{v} 52$.

6. World Health Organization (2003) Diet, Nutrition and the Prevention of Chronic Diseases. Joint WHO/FAO Expert Consultation. WHO Technical Report Series no. 916. Geneva: WHO.

7. Stanner S (editor) (2005) Cardiovascular Disease: Diet, Nutrition and Emerging Risk Factors (The Report of the British Nutrition Foundation Task Force). Oxford: Blackwell Publishing.

8. Gillingham LG, Harris-Janz S \& Jones PJ (2011) Dietary monounsaturated fatty acids are protective against metabolic syndrome and cardiovascular disease risk factors. Lipids 46, 209-228.

9. Ramsden CE, Faurot KR, Carrera-Bastos P, et al. (2009) Dietary fat quality and coronary heart disease prevention: a unified theory based on evolutionary, historical, global, and modern perspectives. Curr Treat Options Cardiovasc Med 11, 289-301.

10. Jenkins DJ, Kendall CW, Axelsen M, et al. (2000) Viscous and nonviscous fibres, nonabsorbable and low glycaemic index carbohydrates, blood lipids and coronary heart disease. Curr Opin Lipidol 11, 49-56.

11. Jenkins DJ, Kendall CW, Faulkner D, et al. (2002) A dietary portfolio approach to cholesterol reduction: combined effects of plant sterols, vegetable proteins, and viscous fibers in hypercholesterolemia. Metabolism 51, 1596-1604.

12. Jenkins DJ, Chiavaroli L, Wong JM, et al. (2010) Adding monounsaturated fatty acids to a dietary portfolio of cholesterol-lowering foods in hypercholesterolemia. CMAJ $\mathbf{1 8 2}$ $1961-1967$.

13. Miller M, Stone NJ, Ballantyne C, et al. (2011) Triglycerides and cardiovascular disease: a scientific statement from the American Heart Association. Circulation 123, 2292-2333.

14. Abdel-Maksoud M, Sazonov V, Gutkin SW, et al. (2008) Effects of modifying triglycerides and triglyceride-rich lipoproteins on cardiovascular outcomes. J Cardiovasc Pharmacol 51, 331-351.

15. Chapman MJ, Ginsberg HN, Amarenco P, et al. (2011) Triglyceride-rich lipoproteins and high-density lipoprotein cholesterol in patients at high risk of cardiovascular disease: evidence and guidance for management. Eur Heart J 32, 1345-1361.

16. Givens DI (2008) Session 4: Challenges facing the food industry in innovating for health. Impact on CVD risk of modifying milk fat to decrease intake of SFA and increase intake of cis-MUFA. Proc Nutr Soc 67, 419-427.

17. Keys A (1965) Effects of different dietary fats on plasmalipid levels. Lancet i, 318-319.

18. Mensink RP, Zock PL, Kester AD, et al. (2003) Effects of dietary fatty acids and carbohydrates on the ratio of serum total to HDL cholesterol and on serum lipids and 
apolipoproteins: a meta-analysis of 60 controlled trials. $\mathrm{Am}$ J Clin Nutr 77, 1146-1155.

19. Minihane AM \& Harland JI (2007) Changing the fat composition of the diet by using improved frying oils. In Nutrition and Health: Current Topics 6-7, pp. 51-57 [T Haffner, editor]. Hertford: Complete Media and Marketing Ltd.

20. Harland JI (2009) An assessment of the economic and heart health benefits of replacing saturated fat in the diet with monounsaturates in the form of canola (rapeseed) oil. Nutr Bull 34, 174-184.

21. Keys A, Menotti A, Karvonen MJ, et al. (1986) The diet and 15-year death rate in the Seven Countries Study. Am J Epidemiol 124, 903-915.

22. Hu FB, Stampfer MJ, Manson JE, et al. (1997) Dietary fat intake and the risk of coronary heart disease in women. $N$ Engl J Med 337, 1491-1499.

23. Swain JF, McCarron PB, Hamilton EF, et al. (2008) Characteristics of the diet patterns tested in the Optimal Macronutrient Intake Trial to Prevent Heart Disease (OmniHeart): options for a heart-healthy diet. J Am Diet Assoc 108, 257-265.

24. Vessby B, Unsitupa M, Hermansen K, et al. (2001) Substituting dietary saturated for monounsaturated fat impairs insulin sensitivity in healthy men and women: The KANWU Study. Diabetologia 44, 312-319.

25. Department of Health (1994) Committee of Medical Aspects of Food Policy (COMA): Nutritional Aspects of Cardiovascular Disease. London: H.M. Stationery Office.

26. Simopoulos AP (2008) The importance of the omega-6/omega-3 fatty acid ratio in cardiovascular disease and other chronic diseases. Exp Biol Med (Maywood) 233, 674-688.

27. European Food Safety Authority (2009) Scientific opinion: Plant stanols and plant sterols and blood LDL-cholesterol. Scientific opinion of the Panel on Dietetic Products, Nutrition and Allergies on a request from the European Commission and a similar request from France in relation to the authorization procedure for health claims on plant stanols and plant sterols and lowering/reducing blood LDL-cholesterol pursuant to Article 14 of Regulation (EC) no 1924/ 2006. Opinion of the Panel on Dietetic Products, Nutrition and Allergies. EFSA J 1175, 1-9.

28. Food and Drug Administration (2000) Food labeling: health claims; plant sterol/stanol esters and coronary heart disease; interim final rule http://www.fda.gov/Food/ LabelingNutrition/LabelClaims/HealthClaimsMeetingSignificantScientificAgreementSSA/ucm074747.htm (accessed August 2012).

29. Katan MB, Grundy SM, Jones P, et al. (2003) Efficacy and safety of plant stanols and sterols in the management of blood cholesterol levels. Mayo Clin Proc 78, 965-978.

30. Law M (2000) Plant sterol and stanol margarines and health. BMJ 320, 861-864.

31. Demonty I, Ras RT, van der Knaap HC, et al. (2009) Continuous dose-response relationship of the LDL-cholesterollowering effect of phytosterol intake. J Nutr 139, 271-284.

32. Abumweis SS, Barake R \& Jones PJ (2008) Plant sterols/ stanols as cholesterol lowering agents: a meta-analysis of randomized controlled trials Food Nutr Res 52 (epublication 18 August 2008).

33. Wu T, Fu J, Yang Y, et al. (2009) The effects of phytosterols/ stanols on blood lipid profiles: a systematic review with meta-analysis. Asia Pac J Clin Nutr 18, 179-186.

34. Musa-Veloso K, Poon TH, Elliot JA, et al. (2011) A comparison of the LDL-cholesterol lowering efficacy of plant stanols and plant sterols over a continuous dose range: results of a meta-analysis of randomized, placebo-controlled trials. Prostaglandins Leukot Essent Fatty Acids 85, 9-28.
35. Talati R, Sobieraj DM, Makanji SS, et al. (2010) The comparative efficacy of plant sterols and stanols on serum lipids: a systematic review and meta-analysis. J Am Diet Assoc 110, 719-726.

36. Anderson JW, Johnstone BM \& Cook-Newell ME (1995) Meta-analysis of the effects of soy protein intake on serum lipids. $N$ Engl J Med 333, 276-282.

37. Reynolds K, Chin A, Lees KA, et al. (2006) A meta-analysis of the effect of soy protein supplementation on serum lipids. Am J Cardiol 98, 633-640.

38. Weggemans RM \& Trautwein EA (2003) Relation between soy-associated isoflavones and LDL and HDL cholesterol concentrations in humans: a meta-analysis. Eur J Clin Nutr 57, 940-946.

39. Zhuo XG, Melby MK \& Watanabe S (2004) Soy isoflavone intake lowers serum LDL cholesterol: a meta-analysis of 8 randomized controlled trials in humans. J Nutr 134, 2395-2400.

40. Balk E, Chung M, Chew P, et al (2005) Effect of soy on health outcomes. In Evidence Report/Technology Assessment no. 126, pp. 1-94. Rockville, MD: Agency for Healthcare Research and Quality.

41. Zhan S \& Ho SC (2005) Meta-analysis of the effects of soy protein containing isoflavones on the lipid profile. Am J Clin Nutr 81, 397-408.

42. Taku K, Umegaki K, Sato Y, et al. (2007) Soy isoflavones lower serum total and LDL cholesterol in humans: a metaanalysis of 11 randomized controlled trials. Am J Clin Nutr 85, 1148-1156.

43. Harland JI \& Haffner TA (2008) Systematic review, metaanalysis and regression of randomised controlled trials reporting an association between an intake of circa $25 \mathrm{~g}$ soya protein per day and blood cholesterol. Atherosclerosis 200, 13-27.

44. Hooper L, Kroon PA, Rimm EB, et al. (2008) Flavonoids, flavonoid-rich foods, and cardiovascular risk: a meta-analysis of randomized controlled trials. Am J Clin Nutr 88, 38-50.

45. Jenkins DJ, Mirrahimi A, Srichaikul K, et al. (2010) Soy protein reduces serum cholesterol by both intrinsic and food displacement mechanisms. J Nutr 140, 2302S-2311S.

46. Anderson JW \& Bush HM (2011) Soy protein effects on serum lipoproteins: a quality assessment and meta-analysis of randomized, controlled studies. J Am Coll Nutr 30, 79-91.

47. Sirtori CR, Eberini I \& Arnoldi A (2007) Hypocholesterolaemic effects of soya proteins: results of recent studies are predictable from the Anderson meta-analysis data. $\mathrm{Br} J$ Nutr 97, 816-822.

48. Jenkins DJA, Mirrahimi A, Srichaikul K, et al. (2010) Soy protein reduces serum cholesterol by both intrinsic and food displacement mechanisms. J Nutr 140, 2302S-2311S.

49. Gardner CD, Messina M, Kiazand A, et al. (2007) Effect of two types of soy milk and dairy milk on plasma lipids in hypercholesterolemic adults: a randomized trial. J Am Coll Nutr 26, 669-677.

50. Joint Health Claims Initiative (2002) Generic health claim for soya protein and blood cholesterol. www.jhci.org.uk (accessed December 2011).

51. Anonymous (1999) Food labeling: health claims; soy protein and coronary heart disease. Food and Drug Administration, HHS. Final rule. Fed Regist 64, 57700-57733.

52. Brown L, Rosner B, Willett WW, et al. (1999) Cholesterollowering effects of dietary fiber: a meta-analysis. $A m \mathrm{~J}$ Clin Nutr 69, 30-42.

53. Ripsin CM, Keenan JM, Jacobs DR Jr, et al. (1992) Oat products and lipid lowering. A meta-analysis. JAMA 267, $3317-3325$. 
54. EFSA Panel on Dietetic Products; Nutrition and Allergies (NDA) (2010) Scientific opinion on the substantiation of a health claim related to oat $\beta$-glucan and lowering blood cholesterol and reduced risk of (coronary) heart disease pursuant to Article 14 of Regulation (EC) no 1924/2006. EFSA J 8, 1885.

55. Talati R, Baker WL, Pabilonia MS, et al. (2009) The effects of barley-derived soluble fiber on serum lipids. Ann Fam Med 7, 157-163.

56. Abumweis SS, Jew S \& Ames NP (2010) $\beta$-Glucan from barley and its lipid-lowering capacity: a meta-analysis of randomized, controlled trials. Eur J Clin Nutr 64, $1472-1480$.

57. Ariyo AA \& Villablanca AC (2002) Estrogens and lipids Can HRT designer estrogens, and phytoestrogens reduce cardiovascular risk markers after menopause? Postgrad Med 111, 23-30.

58. EFSA (2009) Scientific opinion on the substantiation of health claims related to $\beta$-glucans and maintenance of normal blood cholesterol concentrations (ID 754, 755, $757,801,1465,2934)$ and maintenance or achievement of a normal body weight (ID 820, 823) pursuant to Article 13(1) of Regulation (EC) no 1924/20061. EFSA J 7, 1254.

59. EFSA Panel on Dietetic Products; Nutrition and Allergies (NDA) (2011) Scientific opinion on the substantiation of a health claim related to barley $\beta$-glucans and lowering of blood cholesterol and reduced risk of (coronary) heart disease pursuant to Article 14 of Regulation (EC) no 1924/20061. EFSA Journal 9, 2470.

60. Seal CJ (2006) Whole grains and CVD risk. Proc Nutr Soc 65, 24-34.

61. Mellen PB, Walsh TF \& Herrington DM (2008) Whole grain intake and cardiovascular disease: a meta-analysis. Nutr Metab Cardiovasc Dis 18, 283-290.

62. EFSA Panel on Dietetic Products; Nutrition and Allergies (NDA) (2010) Scientific opinion on the substantiation of health claims related to pectins and reduction of post-prandial glycaemic responses (ID 786), maintenance of normal blood cholesterol concentrations (ID 818) and increase in satiety leading to a reduction in energy intake (ID 4692) pursuant to Article 13(1) of Regulation (EC) no 1924/ 2006. EFSA J 8, 1747.

63. EFSA Panel on Dietetic Products; Nutrition and Allergies (NDA) (2011) Scientific opinion on the substantiation of health claims related to chitosan and reduction in body weight (ID 679, 1499), maintenance of normal blood LDLcholesterol concentrations (ID4663), reduction of intestinal transit time (ID 4664) and reduction of inflammation (ID1985) pursuant to Article 13(1) of Regulation (EC) no 1924/2006. EFSA J 9, 2214.

64. Kris-Etherton PM, Hu FB, Ros E, et al. (2008) The role of tree nuts and peanuts in the prevention of coronary heart disease: multiple potential mechanisms. J Nutr 138, 1746S-1751S

65. Mukuddem-Petersen J, Oosthuizen W \& Jerling JCA (2005) systematic review of the effects of nuts on blood lipid profiles in humans. J Nutr 135, 2082-2089.

66. Phung OJ, Makanji SS, White CM, et al. (2009) Almonds have a neutral effect on serum lipid profiles: a meta-analysis of randomized trials. J Am Diet Assoc 109, 865-873.

67. Banel DK \& Hu FB (2009) Effects of walnut consumption on blood lipids and other cardiovascular risk factors: a meta-analysis and systematic review. Am J Clin Nutr 90, 56-63.

68. Damasceno NRT, Pérez-Heras A, Serra M, et al. (2011) Crossover study of diets enriched with virgin olive oil, walnuts or almonds. Effects on lipids and other cardiovascular risk markers. Nutr Metab Cardiovasc Dis 21, Suppl. 1, S14-S20.

69. King JC, Blumberg J, Ingwersen L, et al. (2008) Tree nuts and peanuts as components of a healthy diet. J Nutr $\mathbf{1 3 8}$, 1736S-1740S.

70. EFSA Panel on Dietetic Products; Nutrition and Allergies (NDA) (2010) Scientific opinion on the substantiation of health claims related to Camellia sinensis (L.) kuntze (tea), including catechins in green tea and tannins in black tea, and protection of DNA, proteins and lipids from oxidative damage (ID 1103, 1276, 1311, 1708, 2664), reduction of acid production in dental plaque (ID 1105 , 1111), maintenance of bone (ID 1109), decreasing potentially pathogenic intestinal microorganisms (ID 1116), maintenance of vision (ID 1280), maintenance of normal blood pressure (ID 1546) and maintenance of normal blood cholesterol concentrations (ID 1113, 1114) pursuant to Article 13(1) of Regulation (EC) no 1924/2006. EFSA J 8, 1463.

71. Zhang W, Wang X, Liu Y, et al. (2008) Dietary flaxseed lignan extract lowers plasma cholesterol and glucose concentrations in hypercholesterolaemic subjects. Br J Nutr 99, 1301-1309.

72. Pan A, Yu D, Demark-Wahnefried W, et al. (2009) Metaanalysis of the effects of flaxseed interventions on blood lipids. Am J Clin Nutr 90, 288-297.

73. EFSA Panel on Dietetic Products; Nutrition and Allergies (NDA) (2009) Scientific opinion on the substantiation of health claims related to $\alpha$-linolenic acid and maintenance of normal blood cholesterol concentrations (ID 493) and maintenance of normal blood pressure (ID 625) pursuant to Article 13(1) of Regulation (EC) no 1924/2006 on request from the European Commission. EFSA J 7, 1252.

74. Bazzano LA, Thompson AM, Tees MT, et al. (2011) Non-soy legume consumption lowers cholesterol levels: a metaanalysis of randomized controlled trials. Nutr Metab Cardiovasc Dis 21, 94-103.

75. Khoo YS \& Aziz Z (2009) Garlic supplementation and serum cholesterol: a meta-analysis. J Clin Pharm Ther 34, $133-145$.

76. Rana SV, Pal R, Vaiphe K, et al. (2011) Garlic in health and disease. Nutr Res Rev 24, 60-71.

77. Jenkins DJ, Kendall CW, Marchie A, et al. (2005) Direct comparison of a dietary portfolio of cholesterol-lowering foods with a statin in hypercholesterolemic participants. Am J Clin Nutr 81, 380-387.

78. Jenkins DJ, Jones PJ, Lamarche B, et al. (2011) Effect of a dietary portfolio of cholesterol-lowering foods given at 2 levels of intensity of dietary advice on serum lipids in hyperlipidemia: a randomized controlled trial. JAMA 306 , 831-839.

79. Jenkins DJ, Wong JM, Kendall CW, et al. (2009) The effect of a plant-based low-carbohydrate ("Eco-Atkins") diet on body weight and blood lipid concentrations in hyperlipidemic subjects. Arch Intern Med 169, 1046-1054.

80. Jenkins DJ, Kendall CW, Nguyen TH, et al. (2008) Effect of plant sterols in combination with other cholesterol-lowering foods. Metabolism 57, 130-139.

81. Jenkins DJ, Kendall CW, Faulkner DA, et al. (2006) Assessment of the longer-term effects of a dietary portfolio of cholesterol-lowering foods in hypercholesterolemia. Am J Clin Nutr 83, 582-591.

82. Lamarche B, Desroches S, Jenkins DJ, et al. (2004) Combined effects of a dietary portfolio of plant sterols, vegetable protein, viscous fibre and almonds on LDL particle size. Br J Nutr 92, 657-663.

83. Jenkins DJ, Kendall CW, Marchie A, et al. (2003) Effects of a dietary portfolio of cholesterol-lowering foods vs 
lovastatin on serum lipids and C-reactive protein. JAMA 290, 502-510.

84. Jenkins DJ, Kendall CW, Marchie A, et al. (2003) The effect of combining plant sterols, soy protein, viscous fibers, and almonds in treating hypercholesterolemia. Metabolism 52, 1478-1483.

85. Jenkins DJ, Kendall CW, Mehling CC, et al. (1999) Combined effect of vegetable protein (soy) and soluble fiber added to a standard cholesterol-lowering diet. Metabolism 48, 809-816.

86. Robinson JG \& Maheshwari N (2005) A "poly-portfolio" for secondary prevention: a strategy to reduce subsequent events by up to $97 \%$ over five years. Am J Cardiol 95, 373-378.

87. Jenkins DJ, Kendall CW, Faulkner DA, et al. (2008) Longterm effects of a plant-based dietary portfolio of cholesterol-lowering foods on blood pressure. Eur J Clin Nutr 62, 781-788.

88. Jenkins DJ, Kendall CW, Nguyen TH, et al. (2007) Effect on hematologic risk factors for coronary heart disease of a cholesterol reducing diet. Eur J Clin Nutr 61, 483-492.

89. Gigleux I, Jenkins DJ, Kendall CW, et al. (2007) Comparison of a dietary portfolio diet of cholesterol-lowering foods and a statin on LDL particle size phenotype in hypercholesterolaemic participants. Br J Nutr 98, 1229-1236.

90. Jones PJ, Raeini-Sarjaz M, Jenkins DJ, et al. (2005) Effects of a diet high in plant sterols, vegetable proteins, and viscous fibers (dietary portfolio) on circulating sterol levels and red cell fragility in hypercholesterolemic subjects. Lipids $\mathbf{4 0}$, 169-174.

91. Jenkins DJ, Kendall CW, Marchie A, et al. (2005) Direct comparison of dietary portfolio vs statin on C-reactive protein. Eur J Clin Nutr 59, 851-860.

92. Jenkins DJ, Nguyen TH, Kendall CW, et al. (2008) The effect of strawberries in a cholesterol-lowering dietary portfolio. Metabolism 57, 1636-1644.

93. Minihane AM \& Harland JI (2007) Impact of oil used by the frying industry on population fat intake. Crit Rev Food Sci Nutr 47, 287-297.

94. Deng R (2009) Food and food supplements with hypocholesterolemic effects. Recent Pat Food Nutr Agric 1, 15-24.

95. Brown AW, Hang J, Dussault PH, et al. (2010) Phytosterol ester constituents affect micellar cholesterol solubility in model bile. Lipids 45, 855-862.

96. Vuksan V, Jenkins AL, Rogovik AL, et al. (2011) Viscosity rather than quantity of dietary fibre predicts cholesterollowering effect in healthy individuals. Br J Nutr $\mathbf{1 0 6}$, $1349-1352$.

97. Theuwissen E \& Mensink RP (2008) Water-soluble dietary fibers and cardiovascular disease. Physiol Behav 94, 285-292.

98. Brouns F, Theuwissen E, Adam A, et al. (2012) Cholesterollowering properties of different pectin types in mildly hyper-cholesterolemic men and women. Eur J Clin Nutr 66, 591-599.

99. Manzoni C, Duranti M, Eberini I, et al. (2003) Subcellular localization of soybean $7 \mathrm{~S}$ globulin in HEPg2 cells and LDL receptor up-regulation by its alpha' constituent subunit. J Nutr 133, 2149-2155.

100. Xiao CW, Mei J \& Wood CM (2008) Effect of soy proteins and isoflavones on lipid metabolism and involved gene expression. Front Biosci 13, 2660-2673.

101. Taku K, Umegaki K, Ishimi Y, et al. (2008) Effects of extracted soy isoflavones alone on blood total and LDL cholesterol: meta-analysis of randomized controlled trials. Ther Clin Risk Manag 4, 1097-1103.

102. EFSA Panel on Dietetic Products: Nutrition and Allergies (NDA) (2011) Scientific opinion on the substantiation of health claims related to walnuts and maintenance of normal blood LDL-cholesterol concentrations (ID 1156, 1158) and improvement of endothelium-dependent vasodilation (ID 1155, 1157) pursuant to Article 13(1) of Regulation (EC) no 1924/2006. EFSA J 9, 2074.

103. Theuwissen E \& Mensink RP (2007) Simultaneous intake of $\beta$-glucan and plant stanol esters affects lipid metabolism in slightly hypercholesterolemic subjects. J Nutr 137, 583-588.

104. De Looy AE, Auty PL \& Coates CA (1992) Is our dietary advice effective? Proc Nutr Soc 51, 63-69.

105. Fehily AM, Vaughan-Williams E, Shiels K, et al. (1991) Factors influencing compliance with dietary advice: The Diet and Reinfarction Trial (DART). J Hum Nutr Diet 4, 33-42.

106. Appel LJ, Sacks FM, Carey VJ, et al. (2005) Effects of protein, monounsaturated fat, and carbohydrate intake on blood pressure and serum lipids: results of the OmniHeart randomized trial. JAMA 294, 2455-2464.

107. Yoshida M, Vanstone CA, Parsons WD, et al. (2006) Effect of plant sterols and glucomannan on lipids in individuals with and without type II diabetes. Eur J Clin Nutr 60, 529-537.

108. Van Horn L, Liu K, Gerber J, et al. (2001) Oats and soy in lipid-lowering diets for women with hypercholesterolemia: is there synergy? J Am Diet Assoc 101, 1319-1325.

109. Weidner C, Krempf M, Bard JM, et al. (2008) Cholesterol lowering effect of a soy drink enriched with plant sterols in a French population with moderate hypercholesterolemia. Lipids Health Dis 7, 35.

110. Cicero AF, Minardi M, Mirembe S, et al. (2004) Effects of a new low dose soy protein $/ \beta$-sitosterol association on plasma lipid levels and oxidation. Eur J Nutr 43, 319-322.

111. Cicero AF, Fiorito A, Panourgia MP, et al. (2002) Effects of a new soy/ $\beta$-sitosterol supplement on plasma lipids in moderately hypercholesterolemic subjects. J Am Diet Assoc 102, 1807-1811.

112. Shrestha S, Volek JS, Udani J, et al. (2006) A combination therapy including psyllium and plant sterols lowers LDL cholesterol by modifying lipoprotein metabolism in hypercholesterolemic individuals. J Nutr 136, 2492-2497.

113. Theuwissen E, Plat J \& Mensink RP (2009) Consumption of oat $\beta$-glucan with or without plant stanols did not influence inflammatory markers in hypercholesterolemic subjects. Mol Nutr Food Res 53, 370-376.

114. Lukaczer D, Liska DJ, Lerman RH, et al. (2006) Effect of a low glycemic index diet with soy protein and phytosterols on CVD risk factors in postmenopausal women. Nutrition 22, 104-113.

115. Torres N, Guevara-Cruz M, Granados J, et al. (2009) Reduction of serum lipids by soy protein and soluble fiber is not associated with the $\mathrm{ABCG}_{5} / \mathrm{G} 8$, apolipoprotein $\mathrm{E}$, and apolipoprotein A1 polymorphisms in a group of hyperlipidemic Mexican subjects. Nutr Res 29, 728-735.

116. Baigent C, Blackwell L, Emberson J, et al. (2010) Efficacy and safety of more intensive lowering of LDL cholesterol: a meta-analysis of data from 170,000 participants in 26 randomised trials. Lancet 376, 1670-1681.

117. Holland B, Welch AA and Buss DH, et al (editors) (1997) In McCance and Widdowson's The Composition of Foods, Fifth Revised and Extended Edition. London: The Royal Society of Chemistry and Ministry of Agriculture, Fisheries and Food. 